\title{
The application of cell penetrating peptides for the delivery of neuroprotective peptides/proteins in experimental cerebral ischaemia studies
}

\author{
Amanda J. Meade, $\mathrm{BSc}^{1}$; Bruno P. Meloni, $\mathrm{PhD}^{1,2}$; Frank L. Mastaglia, $\mathrm{PhD}^{1}$; and Neville W. Knuckey, PhD ${ }^{2}$ \\ ${ }^{1}$ Stroke Research Group, Centre for Neuromuscular and Neurological Disorders, The University of Western Australia and Australian \\ Neuromuscular Research Institute, QEII Medical Centre, Nedlands, WA, Australia \\ ${ }^{2}$ Department of Neurosurgery, Sir Charles Gairdner Hospital, Nedlands, WA, Australia
}

\begin{abstract}
The restricted ability of most proteins and peptides to cross the blood-brain barrier and/or plasma membrane limits their use as therapeutics following cerebral ischaemia. However, the discovery of cell-penetrating peptides has provided a means by which such molecules can be transported across the blood-brain barrier and plasma membrane. Many proteins/peptides have already been shown to have neuroprotective properties, and, due to their ability to block protein-protein interactions, provide a potentially rich source of new therapeutic compounds to prevent cell death following cerebral ischaemia. In this review, we give an overview of cellpenetrating peptides and their use experimentally to deliver neuroprotectant proteins/peptides into the brain following cerebral ischaemia.
\end{abstract}

Keywords: Cell penetrating peptides, drug delivery, neuroprotection

\section{Correspondence should be sent to:}

Amanda Meade

Stroke Research Group, Centre for Neuromuscular and Neurological Disorders,

A Block, QEII Medical Centre, Verdun St, Nedlands WA 6009, Australia.

Tel: +61 893461579

Fax: +61 893463487

Email: meadea01@student.uwa.edu.au

Copyright $\odot 2009$ SFES 1939-067X/09

\section{Introduction}

Currently, there is a lack of therapies aimed specifically at reducing neuronal death in the potentially salvageable tissue following cerebral ischaemia. Whilst there have been many clinical trials targeting obvious neuro-damaging pathways (e.g., calcium influx), these have failed because of lack of efficacy or drug toxicity, hence new therapeutic approaches need to be explored. One such approach is to use cell-penetrating peptides (CPP) to deliver agents that were previously not considered as therapeutic candidates due to their poor brain and/or intracellular bioavailability. Many proteins and peptides that have been shown to have neuroprotective activity fall into this category. Moreover, peptides are increasingly being recognised as a new class of therapeutics due to their diversity and ease of synthesis, and their abilities to block and disrupt challenging targets (Watt 2006). Methods to facilitate transduction of proteins and peptides across the blood brain barrier and into the brain include invasive surgical methods, osmotic opening of the blood-brain-barrier, the use of endogenous transport systems, increasing lipophilicity of the molecule, incorporation into nanocarriers, or the fusion of CPPS to the protein or peptide. This review will focus and discuss recent advances in CPPs and their application in the role of delivering neuroprotective proteins and peptides to the brain following cerebral ischaemia.

\section{Cerebral ischaemia and the cell death cascade}

The disruption of blood flow to the brain during an ischaemic event (stroke, cardiac arrest/resuscitation) results in a lack of oxygen and nutrient supply to the brain and a subsequent cellular energy crisis that in turn triggers a cascade of damaging events (Figure 1). The initial stages are associated with neuronal cell depolarisation, glutamate excitotoxicity and calcium overload (Novelli et al. 1988; Nicholls et al. 1990; Goldberg et al. 1993; McCulloch et al. 1993). This leads to secondary effects including a decrease in protein synthesis (Kleihues et al. 1975; Burda et al. 1994; DeGracia et al. 1996), altered mitochondrial function (Rehncrona et al. 1979; Almeida et al. 1995), an increase in lipid peroxidation (Bromont et al. 1989; Haba et al. 1991), oxidative stress, and free radical production (Kader et al. 1993; Chan 2001). Furthermore, multiple signalling pathways are activated, such as the MAPK pathway inducing activation of transcription factors including c-Jun and c-Fos, along with the expression of pro-apoptotic 
genes, even though there is an overall decrease in protein synthesis (Bouwmeester et al. 2004). Additionally, there are post-translational and translocational protein changes as well as an increase in the activity of proteases, lipases and endonucleases (Rosenberg et al. 1996; Gillardon et al. 1997). An inflammatory response and blood brain barrier disruption occurs (Dirnagl et al. 1999) which can further amplify the initial ischaemic injury (Lee et al. 2000). The culmination of these events ultimately leads to cell death exhibiting features of apoptosis, necroptosis, autophagy and necrosis (Lipton 1999; Brott et al. 2000; Degterev et al. 2005). All of these components within the cascade provide opportunities for intervention to limit cell death and brain injury.

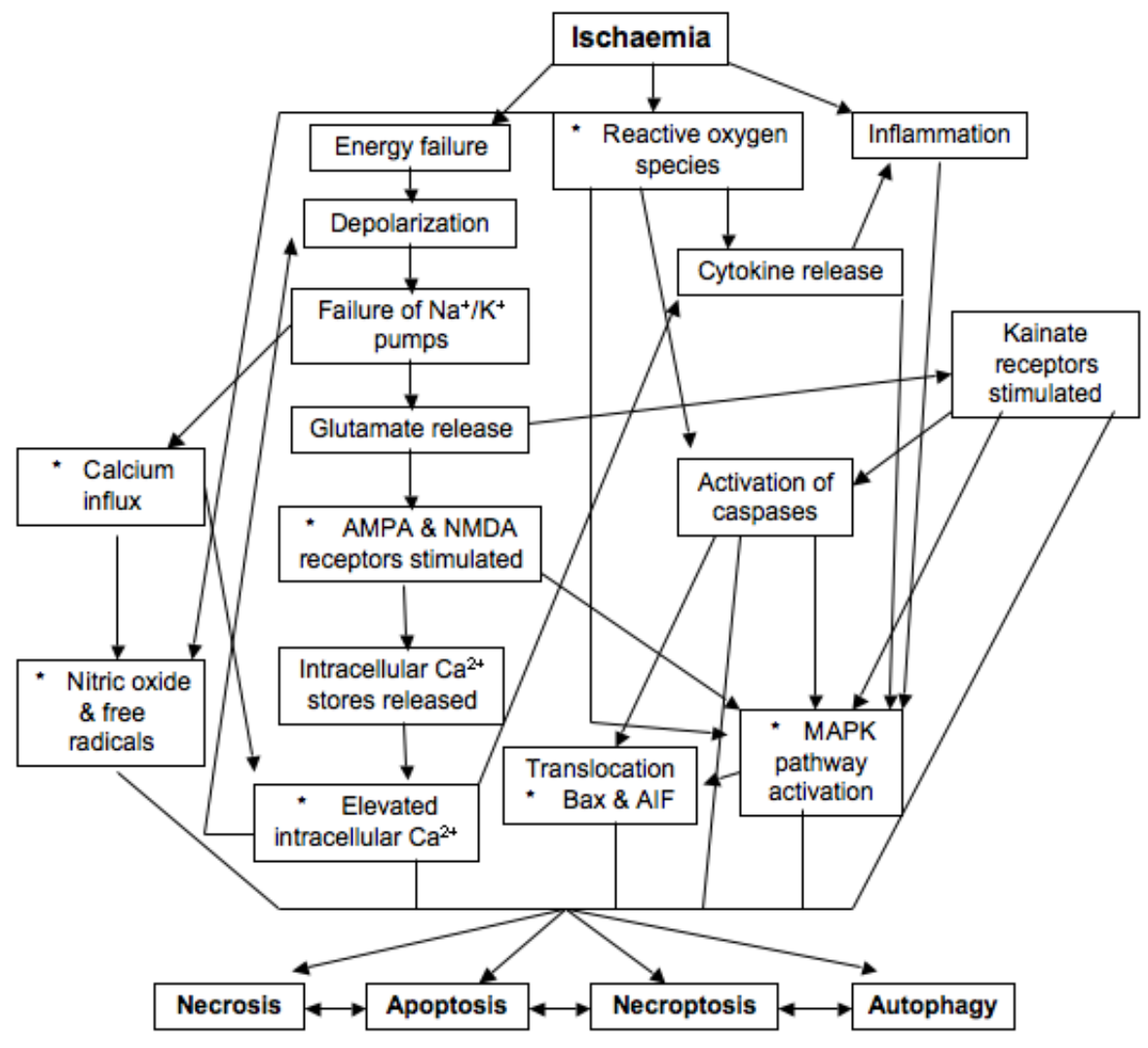

Figure 1. Overview of cell death cascades following cerebral ischaemia. ${ }^{*}$ denotes areas targeted within in vivo studies with CPP-conjugated neuroprotectants (Table 2).

\subsection{Cerebral ischaemia; human impact and current clinical treatments}

In the US alone, in 2002, 1 in 15 deaths were attributed to cerebral ischaemia following a stroke. Whilst mortality is exceedingly high, the burden caused by disability (on the patient, relatives, and the healthcare system) can be just as devastating. Recently, direct and indirect costs associated with cerebral ischaemia are estimated to be US $\$ 56.8$ billion (Pharmaceutical Research and Manufacturers of America 2006).

Currently, the thrombolytic agent tissue plasminogen activator (tPA) is the only pharmaceutical treatment available for ischaemic stroke. However, tPA is only useful when administered intravenously within 4.5 hours of a thrombo-embolic stroke (Hacke et al. 2008). Surgical intervention, in the form of hemicraniectomy to release intracranial pressure, is beneficial for a small subset of stroke patients that undergo malignant cerebral oedema (Dhamija et al. 2007). Moderate hypothermia $\left(33^{\circ} \mathrm{C}\right.$ for $12-24$ hours) is used in comatose survivors following cardiac arrest (Bernard et al. 2002; The Hypothermia After Cardiac Arrest Study Group 2002; Arrich 2007), but requires intensive monitoring of patients and is associated with cardiac arrhythmias, coagulopathy, infection (e.g., pneumonia), and electrolyte disorders (Safar et 
al. 1996; Polderman et al. 2001; Peterson et al. 2008). It is clear that currently available treatments are not ideal and that the development of therapeutic agents with direct neuroprotective activity are urgently required.

\section{Proteins and peptides as therapeutic agents}

The actions of therapeutic proteins are primarily to replace or enhance the activity of endogenous proteins, while therapeutic peptides may inhibit or activate proteins, enzymes, receptors, transporters or biochemical pathways. In contrast, therapeutic peptides target the inhibition or activation of proteins, enzymes, receptors, transporters or biochemical pathways. For example, recombinantly produced human insulin is a protein administered to supplement the endogenous protein for treatment of diabetes mellitus (Goeddel et al. 1979). Similarly, somatostatin analogues are therapeutically administered to enhance the action of endogenous somatostatin in preventing the over production of growth hormone for patients with acromegaly (Croxtall et al. 2008). In contrast, an example of a therapeutic peptide administered to block an endogenous protein is the decapeptide Cetrorelix, which antagonises receptors involved in luteinizing hormone-release and is used in advanced prostate carcinomas, benign prostatic hyperplasia, and ovarian cancer (Reissmann et al. 2000). Another example of a therapeutic peptide is the antiretroviral peptide enfuviritide, which is used in the treatment of HIV infection. Enfuviritide is a synthetic peptide that prevents the transmembrane glycoprotein gp41 fusing with CD4 cells (Cooper et al. 2004; Heil et al. 2004).

An additional clan of protein-based therapeutics are monoclonal antibodies, which have been developed for a number of human disorders including the treatment of acute myeloid leukaemia (Castillo et al. 2008) and psoriasis (Schon 2008). Whilst these disorders are dissimilar, the role of the antibody and subsequent nullification of their target is dependent upon the recognition of a particular antigen. As a result, antibodies are usually only useful against extracellular or cell surface targets. Furthermore, antibodies have poor BBB traversing abilities, as well as a high efflux rate from the brain, with a half-time of 40 min following intra-cerebral injection (Zhang et al. 2001). However, these large groups of proteins and peptides provide substantial proof of concept that proteins and peptides have a therapeutic value clinically.

\subsection{Potential advantages of proteins and peptides as therapeutics}

Traditionally, drug design has been based upon the screening and computational design of small molecules for use as therapeutic agents. This approach typically utilises clefts or pockets present in target proteins that small molecules bind, similar to a 'key and lock' scenario. Therapeutic small molecules have numerous merits besides their small size. They are relatively easy and inexpensive to produce, may be administered orally if required, and can be easily modified to alter potency and other pharmokinetic properties. However, the proficiency of small molecules in preventing or disrupting protein-protein interactions has been lacking, as the interacting sites between proteins are often large without clefts or pockets; this leaves peptides as more suitable candidates for intervention (Archakov et al. 2003; Watt 2006).

\subsection{Peptide modifications to increase stability and half-life}

Peptide stability, and therefore half-life, can be increased with the interchange of L-isoform amino acids with D-isoforms, which reduces proteolysis of the peptide (Brugidou et al. 1995; Wender et al. 2000). When L-isoform amino acids are interchanged for D-isoforms they must be in a retro inverso format to maintain stereospecificity and hence efficacy and specificity (Leker et al. 2002; Borsello et al. 2003). Similarly, amino-acids may be replaced with aminoacid isomers (e.g., norleucine for methionine) that are more resistant to proteolytic degradation (Gozes et al. 1999). Alternatively, linear peptides can be converted to cyclic peptides by the addition of a disulfide-bridge or hydrazide-bridge or another peptide bond to form a more proteolytically resistant lactam ring (Martins et al. 2007). The pegylation of peptides, by the conjugation of polyethylene glycol (PEG), can be used to increase peptide stability, whilst simultaneously decreasing proteolysis, immunogenicity and decreasing efflux across the BBB (Tsubery et al. 2004; Egleton et al. 2005). Finally, peptides can be used as design templates to synthesise molecules that will have improved pharmokinetics with respect to half-life and bioavailability, and that will allow alternative delivery routes such as oral or transcutaneous (Baell et al. 2004; Guan 2008).

\subsection{Other modifications to improve delivery}

Apart from increasing stability and half-life, additional peptide modifications can be performed to improve tissue delivery and specificity. Modifications to minimise peptide size may be performed by identifying and restricting synthesis to the active site of a peptide, thereby simultaneously reducing manufacturing costs and possibly increasing delivery potential (Barr et al. 2002).

Additionally, an "address" localisation sequence can be added to the peptide to facilitate delivery of the 
cargo to specific cell types (e.g., neuronal cells), to organelles (e.g., endoplasmic reticulum or nucleus), or even to ischaemic tissue. Examples of cell specific delivery have been demonstrated with the use of a peptide sequence derived from the rabies virus glycoprotein that binds specifically to the acetylcholine receptor expressed on neurons (Kumar et al. 2007) or the short peptide sequence isolated that targets tumour vasculature (Arap et al. 1998). Moreover, nuclear localisation sequences within endogenous proteins have been extensively identified and characterised (Hu et al. 2005; Russell et al. 2008), and are now being utilised within synthesised peptides (Yoshikawa et al. 2008). Within the brain, the targeted delivery of diphtheria toxin to malignant brain tumors by conjugating it to transferrin, due to the increase of transferrin receptors on malignant brain tumors, has also proved successful and resulted in a lack of systemic toxicity (Laske et al. 1997). Similarly, following cerebral ischaemia, injured tissue can be targeted by the addition of a nine amino-acid sequence that specifically localises to the ischaemic region (Hong et al. 2008).

\section{Delivery of proteins and peptides into the brain}

There are numerous pathways (Figure 1) activated following cerebral ischaemia involving protein-protein interactions, thus providing a plethora of targets for therapeutic intervention. As discussed above, one reason why they have not previously been considered suitable drug targets is the difficulty in disrupting protein-protein interactions. Another reason is the problem of the blood brain barrier (BBB) impeding drug bioavailability to the site of injury.
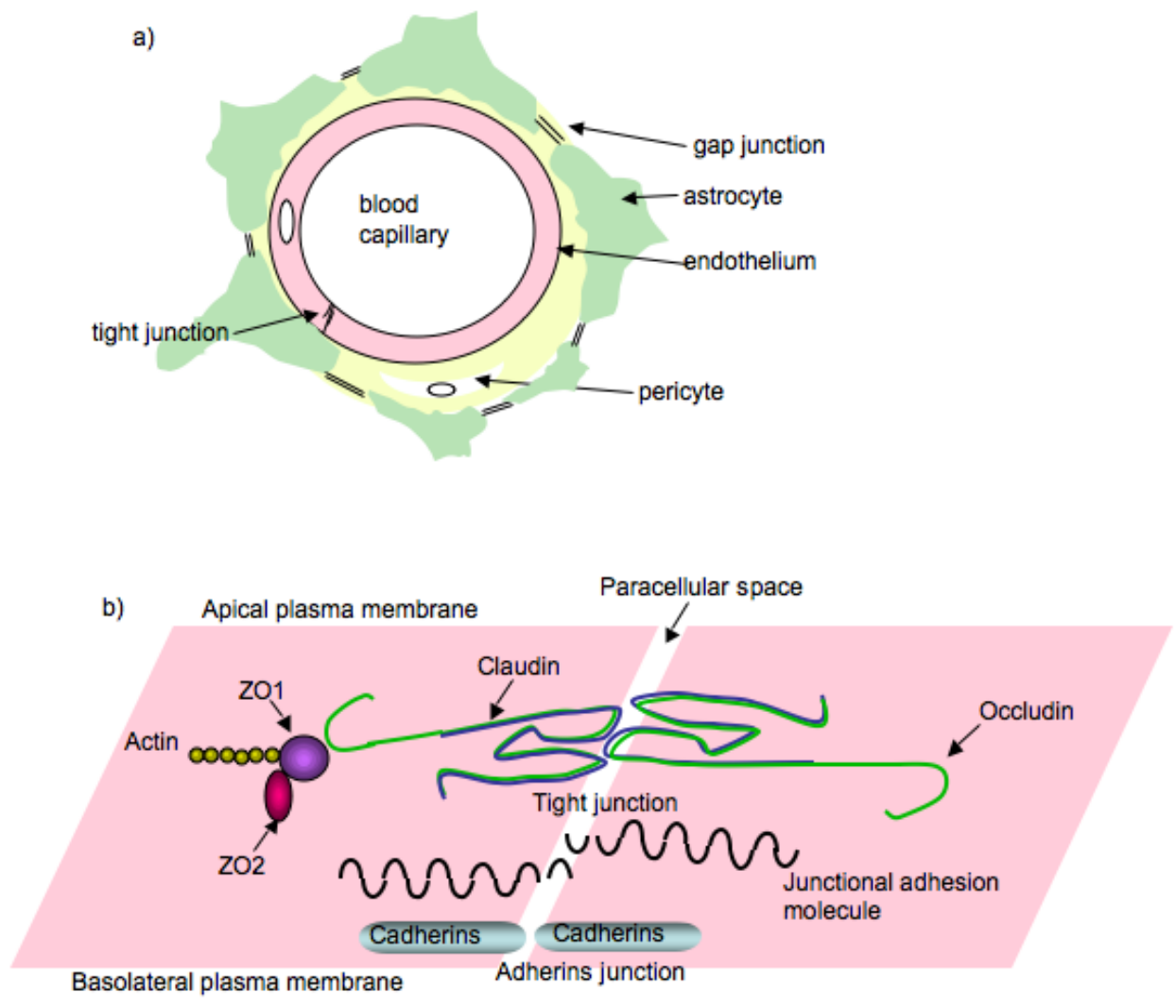

Figure 2. Schematic representation of endothelial cell at the blood brain barrier. a) in transverse section showing endothelial cell, pericyte, basement membrane and astrocytes, and b) showing tight junction and adherins junction between the apposing membranes of the endothelial cell (Adapted from: Ballabh et al. 2004).

\subsection{The blood brain barrier and passive diffusion}

The blood brain barrier (BBB) is an endothelial structure that functions in conjunction with pericytes and astrocytes (Figure 2a) to control the diffusion of molecules from the blood to the extracellular space of the central nervous system and vice versa (Reese et al. 1967; Brightman et al. 1969; Janzer et al. 1987). 
The endothelial cells of the BBB lack fenestrations and have both tight junctions and adherens junctions between the cells limiting permeability (Schulze et al. 1993; Kniesel et al. 2000; Bazzoni et al. 2004) (Figure 2b). This physical barrier along with the noticeable deficiency of pinocytic vesicles results in the prevention of passive diffusion of hydrophilic molecules, although the diffusion of uncharged molecules which are typically small (less than 600Da) and/or lipophilic does occur (Levin 1980; Grieb et al. 1985). Astrocytes further encase the epithelial cells with their extended endfeet projections interspersed with pericytes, which are thought to maintain endothelial stability and integrity (Kacem et al. 1998; Hellstrom et al. 2001). This entire structure allows few therapeutic peptides to diffuse across the BBB and enter the brain.

\subsection{Transport carrier systems that enable therapeutic agents to cross the blood brain barrier}

If unable to diffuse, molecules must cross the BBB via carrier-mediated transport (e.g., glucose via GLUT1, leucine via L1), ion transport (e.g., sodium, potassium and chloride exchangers), active efflux transport (e.g., amphipathic cationic drugs via the multidrug resistance transporter P-glycoprotein), receptor mediated transport (e.g., transferrin and immunoglobulin G), or caveolae-mediated transport (e.g., albumin and insulin) systems (Zlokovic 2008). Peptides can compete to use a carrier system if their structure mimics that of an endogenous molecule that is transported across the BBB. An example of this is biphalin, an opioid analgesic peptide drug, that uses the neutral amino acid carrier system to cross the BBB (Witt et al. 2001).

Peptides that cannot use an endogenous transport system can be fused to a molecule that can be effectively transported across the BBB. This approach has been exploited using molecules such as transferrin and glucose (Witt et al. 2001). Alternatively, peptidomimetic monoclonal antibodies can be utilised to transport cargo across the BBB via a receptor-mediated transport system (Pardridge et al. 1995; Lee et al. 2000). In this case the cargo is fused to the monoclonal antibody, which binds to an external receptor, such as the transferrin or insulin receptor.

The challenges of using a carrier system can include the low density of receptors or transporters on the capillary lumen, the rate of exchange from the blood to the brain, and/or the relative affinity of the endogenous molecule compared to the therapeutic peptide. Thus, in light of the limitations of the carrier system and the likelihood that most proteins and peptides will not be capable of traversing the BBB using this system, other strategies must be employed.

\subsection{Other methods used to enable therapeutic agents to cross the blood brain barrier}

The transport of agents across the BBB using other non-carrier systems can be either invasive or noninvasive. Transient osmotic opening of the BBB by arabinose or mannitol (Rapoport et al. 1980; Siegal et al. 2000), shunts (Alexander et al. 2000), or implanting microspheres (Emerich et al. 1999; Benoit et al. 2000) to deliver therapeutic peptides are invasive methods and have potential side-effects. Osmotic agents can cause accumulation of mannitol in the cerebral tissue and increase oedema, whilst implantations require surgery (Kaufmann et al. 1992; Maioriello et al. 2002). More favourable are noninvasive methods of delivery, such as altering the peptide to increase its membrane permeability, utilising nanocarriers, or attaching a cell penetrating peptide.

Increasing membrane permeability and lipophilicity of peptides

Alterations to increase peptide membrane permeability and lipophilicity include a reduction in molecular weight, reducing hydrogen bond donors to five or less, and limiting hydrogen bond acceptors to no more than 10 (Chikhale et al. 1994; Lipinski et al. 2001). A reduction in molecular weight of a protein or peptide can be achieved by removing unnecessary sections of the peptide to leave only the essential domains or sequence. Methods used to reduce hydrogen bond potential include the addition of nonpolar groups, the removal of polar groups (e.g., hydroxyl groups) or methylation. Additional modifications such as the addition of halogens to the peptide, the acylation or alkylation of the $\mathrm{N}$-terminal of the peptide, variation in the peptide tertiary structure, and glycosylation of peptides can also increase lipophilicity. Glycosylation not only significantly improves dispersal through the BBB, but also increases peptide stability and efficacy (Albert et al. 1993; Negri et al. 1998; Bilsky et al. 2000). There is conjecture over the exact mode of passage for glycosylated peptides with both transport via the glucose transporter (GLUT1) (Namane et al. 1992; Polt et al. 1994; Negri et al. 1998) and entry via adsorptive endocytosis (Palian et al. 2003) being proposed. Of course, any alterations to the peptide to enhance BBB trafficking must not interfere with the affinity and specificity of the peptide for its target.

\section{Nanocarriers}

Nanocarriers are colloidal drug carriers that include liposomes and nanoparticles, which can be utilised to deliver proteins and peptides across the BBB. They 
are administered systemically and have been demonstrated to facilitate targeted delivery to cells, tissues or organs by the external attachment of ligands, such as monoclonal antibodies and cationized bovine serum albumin. Additionally PEG can be bound externally to the nanocarrier to impede the surface deposition of plasma proteins and thereby preventing the uptake of the nanoparticle by macrophages. Extensive reviews detailing the intricacies of various classes of nanocarriers have been published (Beduneau et al. 2007; Brasnjevic et al. 2009).

However, in short, liposomes are engineered to enclose an aqueous phase within a lipid bilayer, similar to biological membranes. The protein or peptide can be incorporated internally into either phase dependent upon their hydrophobic or hydrophilic properties. The liposome is thought to cross the BBB by one of three methods: 1. passive diffusion through the lipophilic endothelial cells; 2 . by endocytosis; 3 . by fusion with brain capillary endothelial cells utilising ligand specific receptors.

Nanoparticles are colloidal structures characterised as comprising of natural or synthetic polymers ranging in size from 1 to $1000 \mathrm{~nm}$. As with liposomes, the protein or peptide is incorporated internally either encased by the polymer matrix or distributed throughout, and can have external additions such as PEG and ligands to increase stability and specificity of targeting, respectively. The nanoparticles are mainly produced by emulsion/solvent evaporation or precipitation solvent diffusion from a variety of polymers such as dextran, starch, gelatin, poly(D,Llactic acid) (PLA), poly(D, L-lactide-co-glycolic acid) (PLGA), and poly(alkylcyanoa-crylate) (PACA). Both liposomes and nanoparticles have been utilised to successfully deliver proteins and peptides to the brain (Kreuter et al. 1995; Gulyaev et al. 1999; Tiwari et al. 2006).

\subsection{Cell penetrating peptides and delivery of peptides to the brain}

\section{Cell penetrating peptides}

Whilst the above methods focus on delivery across the BBB and into the interstitial space, it should be mentioned that therapeutic peptides targeting intracellular interactions will need an additional delivery mechanism to enable entry into the cell. To this end, we will focus on the use of cell penetrating peptides (CPP) to rapidly (and non-invasively) deliver therapeutic peptides across the BBB and into cells.

The use of CPPs to carry peptides and small molecules across the plasma membrane and into cells came about with the discovery of the protein transduction domain (PTD) within the human immunodeficiency virus-type 1 trans-activating transcriptional activator (HIV-1 TAT) in 1988 (Frankel et al. 1988; Green et al. 1988). Since then, the active transporting portion of this sequence has been isolated, as well as the discovery and synthesis of other novel CPPs (Table 1). The conjugation of the CPP and cargo can be achieved by several methods including the use of a disulfide bond between the CPP and cargo, avidin-biotin technology, polyetylen glycol linkers, or direct production of protein fusion with CPP either chemically synthesised or produced using recombinant DNA technology (Pardridge 2002; Mueller et al. 2008; Stewart et al. 2008). The conjugation of the CPP and cargo can be a permanent, stable conjugation or can be designed to be cleaved or become liable in a particular environment, for example, a change in $\mathrm{pH}$ (Rothbard et al. 2000). (Forthwith, for ease of reading, the conjugated CPP with cargo will be generally referred to as CPP-fused, irrespective of actual process involved in the conjugation.)

The method of transduction by TAT, and other CPPS is not fully understood, and initial studies investigating mechanisms were confounded by fixation artifacts (Richard et al. 2003). Three models of transduction are now widely proposed: 1 . direct penetration through the cellular membrane; 2 . endocytosis and then vesicle disruption into the cytoplasm; 3 . inverted micelle formation, engulfment, transport across the cell membrane, and release into the cytoplasm (Joliot et al. 2004; El-Andaloussi et al. 2005).

The amino acid sequence and secondary structure of the CPP and cargo will ultimately determine the mechanism and efficacy of transduction. For example, TAT and polyarginine CPPs are hydrophilic peptides and considered to be transduced by endocytosis (Suzuki et al. 2002; Drin et al. 2003), whilst Penetratin has a hydrophobic core and is postulated to be transduced by inverted micelle formation (Derossi et al. 1994; Nakase et al. 2004). Different mechanisms of transduction for different CPPs is supported by the reduced cellular uptake of arginine-rich CPPs, but not Penetratin, with the treatment of ethylispoprotpylamiloride (EIPA), an endocytosis inhibitor (Nakase et al. 2004). Furthermore, enhanced delivery of both TAT and arginine-rich CPP-cargo conjugates is facilitated by the addition of the $\mathrm{NH} 2$ terminal influenza virus hemagglutinin-2 (HA2) peptide, which evokes the release of complexes trapped within endosomes (Wadia et al. 2004; Michiue et al. 2005). Conversely, MAP and protegrin-1, pore-forming peptides, (Table 1) appear to utilise direct penetration for transduction (Mangoni et al. 1996; Oehlke et al. 1998). 
Table 1 Examples of cell-penetrating peptides

\begin{tabular}{|c|c|c|c|c|}
\hline $\begin{array}{l}\text { Common } \\
\text { name }\end{array}$ & Origin & $\begin{array}{l}\text { Amino acid } \\
\text { sequence }\end{array}$ & Additional features & References \\
\hline TAT & $\begin{array}{l}\text { HIV-1 TAT; residues } \\
48-57\end{array}$ & GRKKRRQRRR & $\begin{array}{l}\text { Able to transduce } 15-120 \mathrm{kDa} \text { proteins \& } \\
\text { peptides into cells in culture with high efficiency } \\
(\sim 100 \%) \text {. In vivo delivery (IV) facilitates } \\
\text { transduction after } 4 \text { hr into various tissues and } \\
\text { across BBB. }\end{array}$ & $\begin{array}{l}\text { (Fawell et al. 1994; Vives et al. } \\
\text { 1997; Schwarze et al. 1999; } \\
\text { Aarts et al. 2002; Cao et al. } \\
\text { 2002) }\end{array}$ \\
\hline $\begin{array}{l}\text { Octarganine or } \\
\text { R8 }\end{array}$ & Polyarginine & RRRRRRRR & $\begin{array}{l}\text { Polyarginine peptides of } 4-16 \text { residues tested } \\
\text { with } 8 \text { and } 9 \text { being optimal. Able to transduce } \\
\text { molecules into a variety of cells in culture. }\end{array}$ & $\begin{array}{l}\text { (Wender et al. 2000; Futaki et al. } \\
\text { 2001; Matsushita et al. 2001) }\end{array}$ \\
\hline $\begin{array}{l}\text { Penetratin } \\
\text { or AntpHD }\end{array}$ & $\begin{array}{l}\text { Antennapedia } \\
\text { homeodomain; } \\
\text { residues } 43-58\end{array}$ & $\begin{array}{l}\text { RQIKIWFQNRRMK } \\
\text { WKK }\end{array}$ & $\begin{array}{l}\text { Entire homeodomain is } 60 \text { residues, consists of } \\
3 \text { alpha-helices. Third helix responsible for } \\
\text { transduction; in vivo delivery into brain within } 30 \\
\text { min following IV administration. }\end{array}$ & $\begin{array}{l}\text { (Joliot et al. 1991; Derossi et al. } \\
\text { 1994; Rousselle et al. 2000) }\end{array}$ \\
\hline FGF or MTS & $\begin{array}{l}\text { Kaposi fibroblast } \\
\text { growth factor; } \\
\text { residues 129-144 }\end{array}$ & $\begin{array}{l}\text { AAVALLPAVLLALLA } \\
\text { P }\end{array}$ & $\begin{array}{l}\text { Hydrophobic peptide, transduces proteins \& } \\
\text { peptides up to } 45 \mathrm{kDa} \text { into cells in culture; in } \\
\text { vivo transduction of enzymatically active } \\
\text { proteins across BBB. }\end{array}$ & $\begin{array}{l}\text { (Delli Bovi et al. 1987; Lin et al. } \\
\text { 1995; Rojas et al. 1996; Rojas et } \\
\text { al. 1998; Jo et al. 2001) }\end{array}$ \\
\hline PEP-1 & & $\begin{array}{l}\text { KETWWETWWTEW } \\
\text { SQPKKKRKV }\end{array}$ & $\begin{array}{l}\text { Contains hydrophobic W-rich domain, } \\
\text { transduces proteins in native conformation into } \\
\text { variety of cells in culture; in vivo delivery across } \\
\text { BBB after IP administration. }\end{array}$ & $\begin{array}{l}\text { (Morris et al. 2001; Sik Eum et } \\
\text { al. 2004) }\end{array}$ \\
\hline DynA & Dynorphin & $\begin{array}{l}\text { YGGFLRRIRPKLKW } \\
\text { DNQ }\end{array}$ & Able to transduce a variety of cells in culture. & (Marinova et al. 2005) \\
\hline Transportan & $\begin{array}{l}\text { Galparan/Mastopora } \\
\mathrm{n}\end{array}$ & $\begin{array}{l}\text { AGYLLGKINLKALAA } \\
\text { LAKKIL }\end{array}$ & $\begin{array}{l}\text { Cherimic peptide form neuropeptide galanin } \\
\text { and membrane interacting wasp venom } \\
\text { peptide, mastoporan. Able to transduce a } \\
\text { variety of cells in culture. }\end{array}$ & $\begin{array}{l}\text { (Langel et al. 1996; Pooga et al. } \\
\text { 1998; Soomets et al. 2000) }\end{array}$ \\
\hline
\end{tabular}


MEADE et al, Cell penetrating peptides and cerebral ischaemia

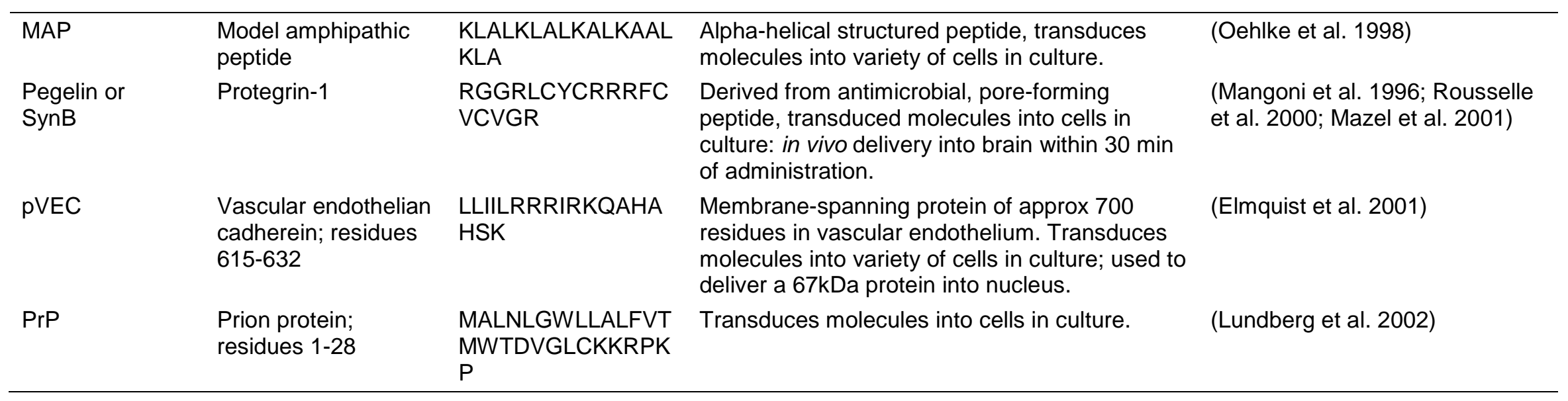

Table 2A. Proteins and peptides, fused to cell penetrating peptides, used as neuroprotectants experimentally in focal cerebral ischaemia models.

\begin{tabular}{|c|c|c|c|c|c|c|c|c|}
\hline $\begin{array}{l}\text { Protein/ } \\
\text { peptide }\end{array}$ & Description/target & CPP & $\begin{array}{l}\text { Animal and } \\
\text { ischaemia } \\
\text { duration }\end{array}$ & Route & $\begin{array}{l}\text { Treatment } \\
\text { schedule }\end{array}$ & $\begin{array}{l}\text { Dose } \mathrm{mg} / \mathrm{kg} \\
\text { (nmoles/kg) }\end{array}$ & $\begin{array}{l}\text { Protection: infarct } \\
\text { volume reduction }\end{array}$ & References \\
\hline \multirow[t]{4}{*}{$\mathrm{Bcl}-\mathrm{X}_{\mathrm{L}}$} & $\begin{array}{l}\text { Interferes with } \\
\text { necrotic and } \\
\text { apoptotic pathways }\end{array}$ & TAT & $\begin{array}{l}\text { Mouse: } \\
\text { 30min }\end{array}$ & IV & $\begin{array}{l}\text { Immediately after } \\
\text { ischaemia }\end{array}$ & $\begin{array}{l}5 \mathrm{mg} / \mathrm{kg} \\
\text { (20nomles/kg) }\end{array}$ & $\begin{array}{l}\text { Yes: reduced } \\
\text { apoptotic and } \\
\text { increased viable } \\
\text { neurons }\end{array}$ & $\begin{array}{l}\text { Kilic et al. } \\
2002\end{array}$ \\
\hline & & & Mouse: & & $60 \mathrm{~min}$ before and & & in striatum & \\
\hline & & & 90min & & $\begin{array}{l}\text { immediately after } \\
\text { ischaemia }\end{array}$ & & $\begin{array}{l}\text { Yes: reduced infarct } \\
\text { volume at both } \\
\text { timepoints }\end{array}$ & \\
\hline & & TAT & $\begin{array}{l}\text { Mouse: } \\
\text { 90min }\end{array}$ & IP & $\begin{array}{l}3 \mathrm{~h} \text { before or } \\
0,45 \text { or } 120 \mathrm{~min} \\
\text { after ischaemia }\end{array}$ & $\begin{array}{l}\text { 9mg/kg } \\
\text { (38nomles/kg) }\end{array}$ & $\begin{array}{l}\text { Yes: } 3 \mathrm{~h} \text { before and up } \\
\text { to } 45 \mathrm{~min} \text { after }\end{array}$ & $\begin{array}{l}\text { Cao et al. } \\
2002\end{array}$ \\
\hline PSD-95 & $\begin{array}{l}\text { Interrupts NMDA } \\
\text { receptor interaction } \\
\text { with PSD95 }\end{array}$ & TAT & Rat: 90min & ICV & $\begin{array}{l}45 \mathrm{~min} \text { before or } \\
60 \mathrm{~min} \text { after } \\
\text { ischaemia }\end{array}$ & 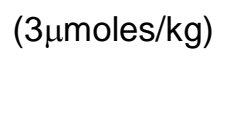 & $\begin{array}{l}\text { Yes: 55\%; before, } \\
67 \% \text {; after }\end{array}$ & $\begin{array}{l}\text { Aarts et al. } \\
2002\end{array}$ \\
\hline
\end{tabular}


MEADE et al, Cell penetrating peptides and cerebral ischaemia

\begin{tabular}{|c|c|c|c|c|c|c|c|c|}
\hline \multirow[t]{4}{*}{ JNKI-1 } & Blocks JNK activity & TAT & $\begin{array}{l}\text { Mouse: } \\
\text { 30min }\end{array}$ & ICV & $\begin{array}{l}3,6,12 \mathrm{~h} \text { after } \\
\text { ischaemia }\end{array}$ & $15.7 n g$ in $2 \mu l$ & $\begin{array}{l}\text { Yes: } 88-93 \% ; 1 \mathrm{~h} \\
\text { before and up to } 6 \mathrm{~h} \\
\text { after ischaemia. No: } \\
12 \mathrm{~h}\end{array}$ & $\begin{array}{l}\text { Borsello et } \\
\text { al. } 2003\end{array}$ \\
\hline & & & $\begin{array}{l}\text { Rat } \\
\text { (neonate): } \\
\text { permanent }\end{array}$ & IP & $\begin{array}{l}30 \mathrm{~min} \text { before or } \\
6 \text { or } 12 \mathrm{~h} \text { after } \\
\text { ischaemia }\end{array}$ & $\begin{array}{l}11 \mathrm{mg} / \mathrm{kg} \\
(2.8 \mu \mathrm{moles} / \mathrm{kg})\end{array}$ & $\begin{array}{l}\text { Yes: 68\%; 30min, } \\
78 \% ; 6 \mathrm{~h}, 49 \% 12 \mathrm{~h}\end{array}$ & \\
\hline & & & Rat: 90min & IV & $6 \mathrm{~h}$ after ischaemia & $\begin{array}{l}0.03,0.1 \text { or } \\
0.3 \mathrm{mg} / \mathrm{kg}\end{array}$ & $\begin{array}{l}\text { Yes: } 37 \% ; 0.1 \mathrm{mg} / \mathrm{kg} \text {. } \\
\text { No: } 0.03,0.3 \mathrm{mg} / \mathrm{kg}\end{array}$ & $\begin{array}{l}\text { Esneault et } \\
\text { al. } 2008\end{array}$ \\
\hline & & & $\begin{array}{l}\text { Mouse: } \\
\text { permanent }\end{array}$ & ICV & $\begin{array}{l}3 \text { or } 6 \text { h after start } \\
\text { of ischaemia }\end{array}$ & 40nmoles in $2 \mu \mathrm{l}$ & $\begin{array}{l}\text { Yes: } 25 \% \text { at } 3 \mathrm{~h} . \text { No: } \\
6 \mathrm{~h}\end{array}$ & $\begin{array}{l}\text { Hirt et al. } \\
2004\end{array}$ \\
\hline GDNF & Neurotrophic factor & TAT & $\begin{array}{l}\text { Mouse: } \\
\text { 30min } \\
\text { Mouse } \\
120 \mathrm{~min}\end{array}$ & IV & $\begin{array}{l}\text { Immediately before } \\
60 \text { min before } \\
\text { Immediately after } \\
\text { ischaemia }\end{array}$ & $\begin{array}{l}0.4 \mathrm{mg} / \mathrm{kg} \\
(20 \mathrm{nmoles} / \mathrm{kg})\end{array}$ & $\begin{array}{l}\text { Yes: reduced infarct } \\
\text { volume } \\
\text { Yes: reduced infarct } \\
\text { volume } \\
\text { No }\end{array}$ & $\begin{array}{l}\text { Kilic et al. } \\
2003\end{array}$ \\
\hline XIAP & & AntpHD & Rat: 120min & IP & $\begin{array}{l}\text { 60min before or } \\
30 \mathrm{~min} \quad \text { after } \\
\text { ischaemia }\end{array}$ & $5 \mathrm{mg} / \mathrm{kg}$ & $\begin{array}{l}\text { Yes: reduced } \\
\text { apoptosis }\end{array}$ & $\begin{array}{l}\text { Fan et al } \\
2006\end{array}$ \\
\hline Calbindin D & $\begin{array}{l}\text { Calcium binding } \\
\text { protein }\end{array}$ & AntpHD & Rat: 60min & IP & $\begin{array}{ll}30 \mathrm{~min} & \text { before } \\
\text { ischaemia } & \end{array}$ & $\begin{array}{l}0.005 \mathrm{mg} / \mathrm{kg} \\
(0.17 \mathrm{nmoles} / \mathrm{kg})\end{array}$ & $\begin{array}{l}\text { Yes: reduced } \\
\text { apoptosis }\end{array}$ & $\begin{array}{l}\text { Fan et al. } \\
2007\end{array}$ \\
\hline
\end{tabular}


MEADE et al, Cell penetrating peptides and cerebral ischaemia

Table 2B. Proteins and peptides, fused to cell penetrating peptides, used as neuroprotectants experimentally in global cerebral ischaemia models.

\begin{tabular}{|c|c|c|c|c|c|c|c|c|}
\hline $\begin{array}{l}\text { Name of } \\
\text { protein/ } \\
\text { peptide }\end{array}$ & $\begin{array}{l}\text { Description/ } \\
\text { target }\end{array}$ & CPP & $\begin{array}{l}\text { Animal and } \\
\text { ischaemia } \\
\text { duration }\end{array}$ & Route & $\begin{array}{l}\text { Timeframe of } \\
\text { treatment }\end{array}$ & $\begin{array}{l}\text { Dose } \mathrm{mg} / \mathrm{kg} \\
\text { (nmoles/kg) }\end{array}$ & $\begin{array}{l}\text { Protection: CA1 } \\
\text { neuronal survival }\end{array}$ & References \\
\hline FNK & $\begin{array}{l}\text { Modified Bcl-XL } \\
\text { protein. } \\
\text { Interferes with } \\
\text { necrotic and } \\
\text { apoptotic } \\
\text { pathways }\end{array}$ & TAT & Gerbil: $5 \mathrm{~min}$ & IP & $\begin{array}{l}\text { 3h before } \\
\text { ischaemia }\end{array}$ & $\begin{array}{l}5 \text { mg/kg } \\
\text { (20nomles/kg) }\end{array}$ & $\begin{array}{l}\text { Yes: increased } \\
\text { CA1 survival from } \\
<1 \% \text { to } 16-89 \%\end{array}$ & $\begin{array}{l}\text { Asoh et al. } \\
2002\end{array}$ \\
\hline \multirow[t]{2}{*}{ SOD1 } & Anti-oxidant & PEP1 & Gerbil: $5 \mathrm{~min}$ & $\mathrm{IP}$ & $\begin{array}{l}30 \text { min before or } \\
\text { immediately after } \\
\text { ischaemia }\end{array}$ & $\begin{array}{l}2,4,6,8 \text { or } 10 \mathrm{mg} / \mathrm{kg} \\
(115-570 \mathrm{nmoles} / \mathrm{kg})\end{array}$ & $\begin{array}{l}\text { Yes: increased CA1 } \\
\text { survival from } 11 \% \\
\text { to } 85-92 \%\end{array}$ & $\begin{array}{l}\text { Sik Eum et al } \\
2004\end{array}$ \\
\hline & & TAT & Gerbil: $5 \mathrm{~min}$ & IP & $\begin{array}{l}30 \mathrm{~min} \text { before or } \\
\text { immediately after } \\
\text { ischaemia }\end{array}$ & $\begin{array}{l}1.4-4 \mathrm{mg} / \mathrm{kg} 7 \mathrm{mg} / \mathrm{kg} \\
\text { (400nmoles/kg) }\end{array}$ & $\begin{array}{l}\text { Yes: increased CA1 } \\
\text { survival from } 14 \% \\
\text { to } 46 \%\end{array}$ & $\begin{array}{l}\text { Kim et al. } \\
2005\end{array}$ \\
\hline $\begin{array}{l}\text { Copper } \\
\text { chaperone } \\
\text { for SOD }\end{array}$ & $\begin{array}{l}\text { Increase anti- } \\
\text { oxidant effect of } \\
\text { SOD }\end{array}$ & PEP1 & Gerbil: $5 \mathrm{~min}$ & IP & $\begin{array}{l}30 \mathrm{~min} \text { before } \\
\text { ischaemia }\end{array}$ & $4 \mathrm{mg} / \mathrm{kg}$ & $\begin{array}{l}\text { Yes: increased CA1 } \\
\text { survival from } 11 \% \\
\text { to } 43 \%\end{array}$ & $\begin{array}{l}\text { Choi et al. } \\
2005\end{array}$ \\
\hline GluR6-9c & $\begin{array}{l}\text { Interferes with } \\
\text { GluR6 -PSD95 } \\
\text { complex }\end{array}$ & TAT & Rat: 15min & ICV & $\begin{array}{l}40 \mathrm{~min} \text { before } \\
\text { ischaemia }\end{array}$ & $100 \mu \mathrm{g}$ in $10 \mu \mathrm{l}$ & $\begin{array}{l}\text { Yes: increased CA1 } \\
\text { survival from } 14 \% \\
\text { to } 46 \%\end{array}$ & $\begin{array}{l}\text { Pei et al. } \\
2006\end{array}$ \\
\hline JIP & $\begin{array}{l}\text { Blocks JNK } \\
\text { activity }\end{array}$ & TAT & Rat: 15min & ICV & $\begin{array}{l}40 \mathrm{~min} \text { before or } 1 \mathrm{~h} \\
\text { after ischaemia }\end{array}$ & $100 \mu \mathrm{g}$ in $10 \mu \mathrm{l}$ & $\begin{array}{l}\text { Yes: increased } \\
\text { neuronal survival }\end{array}$ & $\begin{array}{l}\text { Guan et al. } \\
2006\end{array}$ \\
\hline
\end{tabular}

- 31 -

J Exp Stroke Transl Med (2009) 2(1): 22-40

Society for Experimental Stroke (www.s4es.org) 


\section{Delivery into the brain}

Eleven years after the discovery of the TAT CPP, Schwarze et al. (1999) showed that TAT could transduce the BBB. In this instance, fluorescently labelled TAT was visible throughout the brain 20 minutes after intraperitoneal (IP) administration in the mouse. Furthermore, Schwarze et al. (1999) demonstrated the transport of a biologically active $\beta$ galactosidase enzyme-TAT conjugate across the BBB after two hours and into many regions of the brain after four hours following IP administration. Similarly, following IP or IV administration, Jo et al. (2001) demonstrated transduction of a biologically active CRE protein conjugated to the MTS CPP into the brain. The delivery of non-protein molecules into the brain has also been achieved with CPPs. For example, the anticancer drug doxorubicin, coupled with the SynB and Penetratin CPPs, was detectable in the brain 30 minutes after IV administration (Rousselle et al. 2000).

In vitro neuronal studies with neuroprotectants fused to cell penetrating peptides
Since the transduction efficacy of CPPs varies in relation to the cargo and cell type (Fischer et al. 2002; Peitz et al. 2002; Mueller et al. 2008) it is important to validate transduction using relevant in vitro culture systems. For example, preliminary data from our laboratory has demonstrated that for the same neuroprotective peptides $(5 \mu \mathrm{M}$ of PYC36D or PYC35D) fused to either the MTS or TAT CPPs, only the TAT fused peptides were effective in an in vitro neuronal glutamate injury model (Figure 3). Whilst there have been several studies which successfully utilised MTS (Lin et al. 1995; Rojas et al. 1998), Peitz et al (2002) also reported a greater level of transduction with their TAT-fused cargo as opposed to MTS-fused cargo. This lack of neuroprotection with MTS fused peptides may be due to several factors including steric hindrance from the CPP, formation of secondary or tertiary structure within and between the peptide and CPP, or from limited transduction of the peptide.

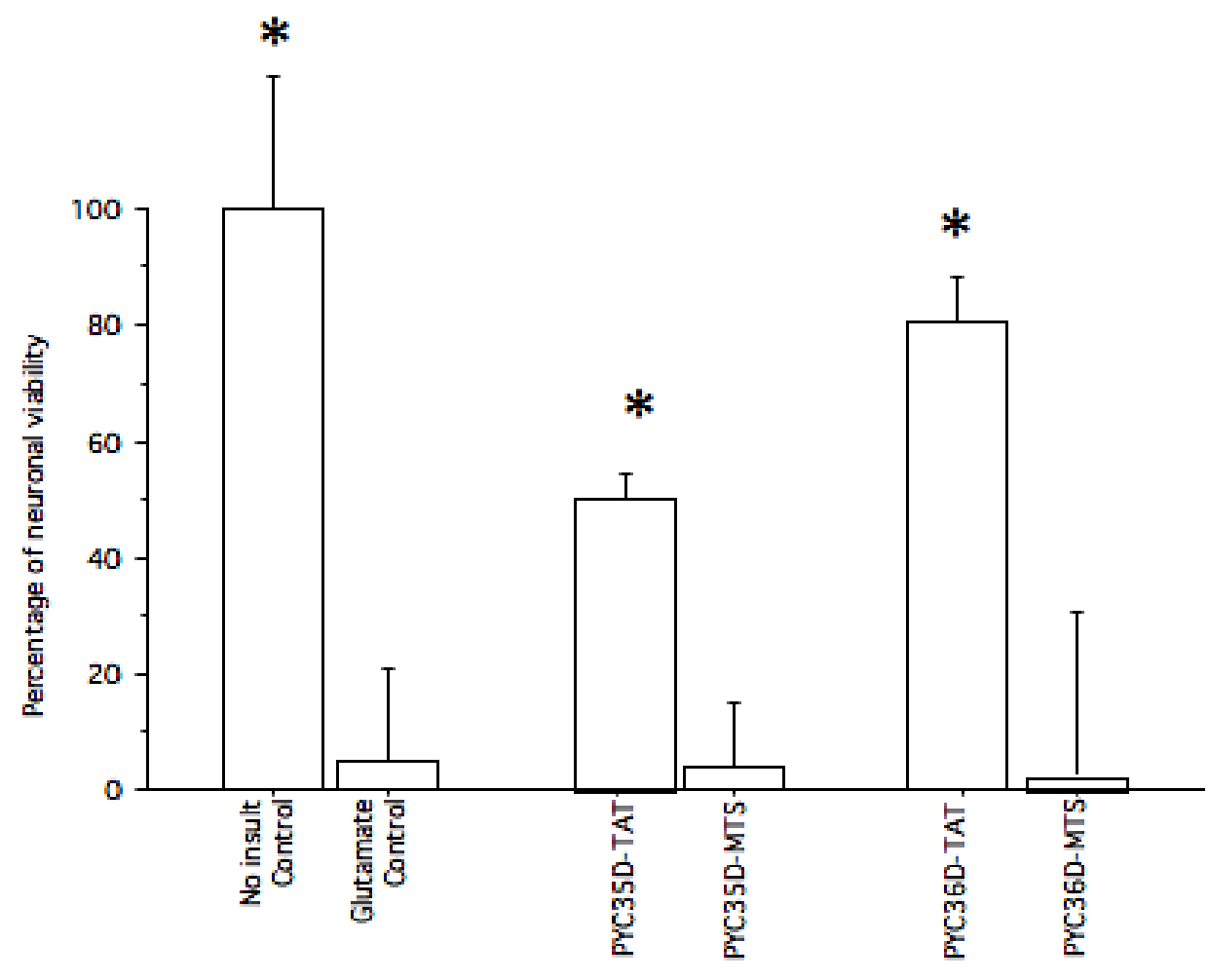

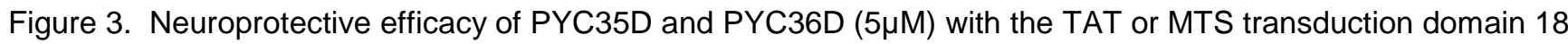
hours following glutamate exposure. Peptides administered to primary neuronal cultures 15 minutes prior to $100 \mu \mathrm{M}$ (final concentration) glutamate exposure for 5 minutes. Neuronal viability expressed as a percentage, with no insult control taken as $100 \%$ viability (mean \pm SEM; $n=4 ;{ }^{* *} p<0.0001$ ). 
Similarly, despite the demonstration that CPPs could deliver cargo across BBB and into the brain, most in vivo animal studies have been preceded by in vitro culture studies. For example, in vitro neuronal culture systems that mimic neuronal injury mechanisms in a variety of disorders, including cerebral ischaemia, epilepsy, Parkinson's and Alzheimer's Diseases, have been used to assess neuroprotective efficacy for CPP fused proteins or peptides (Lai et al. 2005; Liu et al. 2006; Arthur et al. 2007; Colombo et al. 2007; Nagel et al. 2008). These studies also provided an indication of potential effective in vivo doses, especially if pharmokinetic data is available for the protein or peptide being tested (Borsello et al. 2003; Hirt et al. 2004; Sik Eum et al. 2004; Fan et al. 2006).

\section{CPPs used to deliver neuroprotective peptides in experimental cerebral ischaemia models}

Following the demonstration of the ability of CPPs to traverse the BBB it was not long before CPPs were used to deliver neuroprotective peptides into the brain in animal models of cerebral ischaemia. To date, more than 10 different peptides fused to CPPs have been trialled in experimental models of focal and global cerebral ischaemia (Table 2). These studies have predominantly resulted in a significant reduction in brain injury and, when assessed, improved functional outcomes in treated animals. Since experimental studies with CPP-fused neuroprotectants in ischaemic models have differed considerably in respect to the class of therapeutic, route, dose and timing of treatment, they are further discussed below.

\subsection{Studies using endogenous proteins}

In two of the initial animal studies (Cao et al. 2002; Kilic et al. 2002) the anti-apoptotic protein Bcl-XL, fused to the TAT peptide, showed significant neuroprotective activity in mouse transient focal cerebral ischaemia models. Kilic et al. (2002) reported that a $20 \mathrm{nmol} / \mathrm{kg}$ dose administered IV 1 hour before or immediately post middle cerebral artery occlusion (MCAO) significantly reduced infarct volume when assessed at 48 hours. Cao et al. (2002) used a substantially higher $(360 \mathrm{nmol} / \mathrm{kg}$ ) dose of $\mathrm{Bcl}-\mathrm{XL}$ administered IP. This treatment reduced infarct volume when given immediately before and 45 minutes after MCAO, but not 2 hours after occlusion. In a third study, Asoh et al. (2002) assessed the efficacy of a mutated, more potent form of $\mathrm{Bcl}-\mathrm{XL}$, named FNK, in a mouse global cerebral ischaemia model. In this study, the FNK-TAT conjugate administered IP at $20 \mathrm{nmol} / \mathrm{kg}, 3$ hours before ischaemia, significantly increased hippocampal CA1 neuronal survival.
In 2003, Kilic et al. showed that the neurotrophic factor GDNF, fused to TAT, was effective at reducing infarct volume in the mouse following 30 minutes of transient focal ischaemia. The GDNF-TAT protein was administered IV at a $20 \mathrm{nmol} / \mathrm{kg}$ dose, immediately post-ischaemia. When the duration of MCAO was extended to 120 mins, GDNF-TAT was effective when administered 1 hour before ischaemia, but ineffective when administered immediately postischaemia (Kilic et al. 2003).

Three studies (Sik Eum et al. 2004; Choi et al. 2005; Kim et al. 2005) have assessed the antioxidant enzyme SOD, fused to either TAT or to PEP-1 in gerbil global cerebral ischaemia models. In two of the studies SOD was administered IP at doses ranging from $115-570 \mathrm{nmol} / \mathrm{kg}$ either 30 mins prior to ischaemia or immediately post-ischaemia. CA1 survival was then examined after four days. The study, performed by Sik Eum et al. (2004), showed that the SOD-PEP-1 protein was equally neuroprotective when administered either prior to or post-ischaemia, within each dose. At a dose of $170 \mathrm{nmol} / \mathrm{kg}$, SOD-PEP-1 resulted in $85 \%$ survival of neurons in the CA1 region of the hippocampus. Neuronal survival increased to $92 \%$ when the dose of SOD-PEP-1 was increased to $570 \mathrm{nmol} / \mathrm{kg}$. However, Kim et al. (2005) required the maximum dose of $570 \mathrm{nmol} / \mathrm{kg}$ to provide neuroprotection, with a marked difference in neuronal survival between the pre- and post-ischaemic administration of SOD-TAT. Pre-ischaemic administration of SOD-TAT resulted in $65 \%$ neuronal survival, whilst animals that were postadministered achieved $45 \%$ neuronal survival. The third study administered the copper chaperone for SOD (CCS) fused to PEP-1, IP, 30 mins prior to ischaemia and examined CA1 survival after four days. Similarly, Choi et al. (2005) showed the CCS-PEP-1 protein increased neuronal survival to $46 \%$, in addition to finding a 3-4 fold increase in SOD activity.

The use of the caspase inhibitor XIAP has been assessed in both mouse permanent and transient focal ischaemia models. Guegan et al. (2006) initially applied XIAP-TAT in a gel foam $(50 \mathrm{nmol} / \mathrm{kg}$ ) and inserted it into a craniotomy immediately post-MCAO, which resulted in a significant infarct volume reduction. However, IV administration of the XIAPTAT at a $50 \mathrm{nmol} / \mathrm{kg}$ dose revealed the protein did not accumulate in the brain. This led to the production of a truncated version of the protein from $62 \mathrm{kDa}$ down to approximately $16 \mathrm{kDa}$, which was then shown to accumulate in the brain. Subsequent IV administration of the truncated XIAP-TAT protein at a $50 \mathrm{nmol} / \mathrm{kg}$ dose resulted in significant infarct volume reduction when given 30 minutes before, or 30 or 180 minutes after, ischaemia. Coincidently, Fan et al. (2006) produced a similar truncated XIAP protein 
fused to the Penetratin CPP. A 250nmol $/ \mathrm{kg}$ dose of the truncated XIAP-Penetratin conjugate administered IP one hour before or 30 minutes after transient focal ischaemia significantly reduced the number of ischaemic perifocal cells and behavioural deficits in treated animals compared to controls. Fan et al. (2007) also fused Penetratin with the calciumbinding protein calbindin $\mathrm{D}$ and showed that IP administration at $0.17 \mathrm{nmol} / \mathrm{kg} 30$ minutes before transient focal ischaemia in the mouse resulted in significantly decreased infarct volume.

\subsection{Studies using peptides derived from signaling protein domains}

\section{Peptides targeting glutamate receptor signaling}

Several studies have used CPPs fused to small peptides derived from regions of signaling proteins as competitive inhibitors of protein-protein interactions. The first to use this approach was Aarts et al. (2002), who used a nine amino-acid peptide (NR2B9c) derived from the intracellular domain of the NMDA receptor NR2 subunit. This region of the NR2 protein interacts with the post synaptic density-95 (PSD-95) adaptor protein to activate nNOS and generate nitric oxide. When administered intracerebroventricularly (ICV), either before or 1 hour after transient focal ischaemia in the rat, NR2Bc-TAT reduced infarct volumes and improved behavioural outcomes when assessed at 24 hours. Using a similar approach, Pei et al. (2006) utilised a nine amino-acid peptide derived from the glutamate receptor subunit protein (GluR6-9c) region which binds to PSD-95 and activates downstream signalling pathways, such as the MAPK pathway. The ICV administration of this peptide fused to TAT 40 minutes before global ischaemia in the rat significantly increased hippocampal CA1 neuronal survival.

\section{Peptides targeting JNK signaling}

In 2003, the first of four studies detailing the use of a 20 amino-acid peptide named JNKI-1, derived from the JNK scaffold protein JIP, in models of cerebral ischaemia, was reported. The JIP protein is required by JNK during phosphorylation of target proteins, and the 20 amino-acid JNKI-1 region is a critical JNK-JIP binding domain, which the JNKI-1 peptide competitively inhibits. For in vivo experiments, Borsello et al. (2003) used JNKI-1 fused to TAT, synthesising the peptide (JNKI-1D-TAT) using Disoform amino acids in a retro-inverso orientation to increase peptide half-life and to maintain peptide chirality. In one part of this study JNKI-1D-TAT (15.7ng) was administered ICV 1 hour before, or 3, 6, or 12 hours after, transient focal ischaemia in the mouse. Treatment with JNKI-1D-TAT at all timepoints, except at 12 hours after ischaemia, resulted in significant decreases in infarct volumes and improved behavioural outcomes when assessed at 1 or 14 days post-ischaemia. In a second part of the study, JNKI-1D-TAT was administered IP (2800 $\mathrm{nmol} / \mathrm{kg}) 30$ minutes before, or 6 or 12 hours after, permanent focal ischaemia in 14 day old rats. In these experiments JNKI-1D-TAT significantly reduced infarct volumes at all time points when assessed 7 days post-ischaemia.

Two other research laboratories have also assessed the efficacy of JNKI-1D-TAT in cerebral ischaemia models. Esneault et al. (2008) administered JNKI1D-TAT IV at three different doses $(85,250$, $750 \mathrm{nmol} / \mathrm{kg}$ ) 3 hours after transient focal ischaemia in the rat. While all three different doses were compared and resulted in a decrease in infarct volume, only the $250 \mathrm{nmol} / \mathrm{kg}$ dose reached statistical significance with respect to infarct volume reduction and improved sensorimotor and cognitive function. Additionally, Hirt et al. (2004) administered JNKI-1DTAT ICV $(1400 \mathrm{nmol} / \mathrm{kg})$ to mice 3 or 6 hours after permanent focal ischaemia. Administration of JNKI1D-TAT at the 3 hour, but not the 6 hour, time point resulted in significantly decreased infarct volumes when assessed at one day post-ischaemia.

Additionally, an 11 amino-acid truncated version of JNKI-1, annotated as JIP, was assessed in a global cerebral ischaemia rat model (Guan et al. 2006). The truncated JIP, fused to TAT, was administered ICV $(100 \mu \mathrm{g})$, either 40 minutes before or 1 hour after ischaemia, and resulted in a significant increase in the number of surviving CA1 neurons.

\section{Peptides targeting the Nogo receptor}

A recent study by Wang et al. (2008) used a 40 amino-acid peptide (NEP1-40), designed to antagonise the Nogo receptor, which, when activated, inhibits neuronal growth and re-generation, in a rat transient focal ischaemia model. NEP1-40 fused to TAT was administered IP (120 $\mathrm{nmol} / \mathrm{kg})$ immediately after ischaemia, and significantly reduced infarct volumes when compared to control animals.

\subsection{Summary and significance of CPP delivered neuroprotective proteins and peptides}

These studies using endogenous proteins or peptides from signalling protein domains fused to CPPs, have established proof of principle of CPPs as therapeutic delivery facilitators across the BBB, and have successfully shown the potential of protein and peptides as therapeutic neuroprotectants. As these proteins and peptides aid in neuroprotection at various stages of the ischaemic death cascade (Figure 1), and are able to be directed at both intracellular and extracellular targets, further benefit may arise from a cocktail of endogenous proteins rather than just their administration in isolation. The 
administration of therapeutic proteins and peptides has been effective both IV and IP, increasing their versatility as therapeutic agents. In addition, both the wild-type and mutated forms of endogenous proteins and peptides appear to be safe and well tolerated, with a lack of toxicity or immunogenicity reported. However, the variability between the studies with regard to effective dosage and administration timepoints highlights the requirement for assessment of each protein/peptide individually before being trialled in the clinical setting.

\section{The onset of clinical trials for therapeutic peptides in neurological disorders}

The research conducted with the JNKI-I neuroprotective peptide in the animal models of cerebral ischaemia administered by a clinically relevant route (IV) and within an appropriate timeframe has resulted in its further development as a therapeutic candidate. The Biopharmaceutical Company Xigen is pursuing JNKI-1 (XG-102) in a Phase 1 trial following cerebral ischaemia, which has not been fully disclosed. Research to ensure its compatibility with rtPA has been successfully performed in a 30 minute suture MCAO model of cerebral ischaemia in mouse. In this model, rtPA $(0.9 \mathrm{mg} / \mathrm{kg})$ was administered 3 hours after ischaemia and XG-102 $(0.1 \mathrm{mg} / \mathrm{kg})$ administered 6 hours after ischaemia, IV. A significant reduction in infarct volume and improved behavioural outcomes were achieved (Wiegler et al. 2008), further demonstrating the feasibility of this neuroprotectant to be therapeutically effective in a clinically relevant timeframe.

\section{Other potential advantages of CPPs as pharmaceutical delivery systems}

An important feature of any CPP is that it has limited toxicity at clinically relevant doses, while a CPP that displays endogenous neuroprotective activity is an added advantage. In fact, this appears to be the case, at least for TAT. A recent study (Wei et al. 2008) has reported that at high concentrations the TAT peptide displays neuroprotective properties in a hippocampal slice oxygen-glucose deprivation model. In addition, pilot studies in our laboratory have confirmed that with increasing dose, TAT is neuroprotective in a glutamate excitotoxicity model. While the exact mechanisms of TAT's neuroprotective action is not fully understood, Wei et al. (2008) has suggested it is related TAT's ability to transverse cell membranes and thereby interfere with membrane proteins, receptors and signalling. Interestingly, a RNAi study using CPPs to deliver constructs, both the TAT and Penetratin peptides alone were shown to down-regulate MAP kinase mRNA in the lung following intratracheal administration (Moschos et al. 2007). Hence, while further work is required to elucidate and even enhance TAT's neuroprotective actions, it appears that it is an excellent carrier molecule for therapeutic delivery of neuroprotective agents into the brain.

\section{Potential limitations of CPPs as delivery system for pharmaceuticals}

The ability of CPPs to transduce cellular membranes comes with its own set of limitations. Whilst CPP. fused delivery of cargo enables immediate access of the cell to the cargo, it results in non-targeted wide dissemination of the therapeutic throughout the body. Depending on the mechanistic action of the CPPfused therapeutics this may require the need for high or continual dosing of the agent and an associated increased risk of side-effects. Hence, the ability to modify CPPs in order to target specific tissue or organs (eg ischaemic tissue or brain) could potentially reduce the risk of systemic side-effects. It is also possible that the CPP delivery system may not be able to achieve therapeutic concentrations in target cells/tissue and/or that the CPP peptide may interfere with the protein/peptides mechanism of action. In the case of CPP interference with the cargo, a design that results in the cleavage of the CPP would be required (Rothbard et al. 2000).

With respect to any side-effects associated with CPPfused therapeutics, it will also be important to delineate any toxic effects caused by the CPP or peptide/protein component of the therapeutic agent. In vitro toxicity studies of various CPPs have been reported with minimal cytotoxicity at concentrations regarded as optimal for drug delivery, and increasing at concentrations well above expected therapeutic doses (Nath et al. 1996; Mueller et al. 2008). To date, clinical trials using TAT and R7 fused agents have not been associated with any serious side-effects (Rothbard et al. 2000; Chen et al. 2007).

\section{Conclusion}

The ability of CPPs to transport molecules across the BBB and plasma membranes and into cells has increased both the range of targets and the class of therapeutic compounds, namely peptides and proteins, available for neuroprotective interventions. Previously, delivery of therapeutics for neurological disorders such as cerebral ischaemia has only been possible via invasive methods, which not only comes with its own set of complications but also extends the timeframe before therapies may be administered. The advent of CPPs with their rapid and efficient transduction across the BBB and plasma membrane brings about the opportunity for novel therapeutics to be administered in a more clinically relevant timeframe, enhancing the probability of intervening in 
cell-death cascades and ultimately improving patient outcome.

\section{Acknowledgement}

This work was supported by the Scholarships provided by the University of Western Australia and Phylogica Ltd.

\section{References}

Aarts, M., Y. Liu, L. Liu, S. Besshoh, M. Arundine, J. W. Gurd, Y. T. Wang, M. W. Salter and M. Tymianski Treatment of ischemic brain damage by perturbing NMDA receptor- PSD-95 protein interactions. Science. 2002;298(5594):846-50.

Albert, R., P. Marbach, W. Bauer, U. Briner, G. Fricker, C. Bruns and J. Pless SDZ CO 611: a highly potent glycated analog of somatostatin with improved oral activity. Life Sci. 1993;53(6):517-25.

Alexander, B., X. Li, I. S. Benjamin, M. B. Segal, R. Sherwood and J. E. Preston A quantitative evaluation of the permeability of the blood brain barrier of portacaval shunted rats. Metab Brain Dis. 2000;15(2):93-103.

Almeida, A., K. L. Allen, T. E. Bates and J. B. Clark Effect of reperfusion following cerebral ischaemia on the activity of the mitochondrial respiratory chain in the gerbil brain. $\mathrm{J}$ Neurochem. 1995;65(4):1698-703.

Arap, W., R. Pasqualini and E. Ruoslahti Cancer treatment by targeted drug delivery to tumor vasculature in a mouse model. Science. 1998;279(5349):377-80.

Archakov, A. I., V. M. Govorun, A. V. Dubanov, Y. D. Ivanov, A. V. Veselovsky, P. Lewi and P. Janssen Protein-protein interactions as a target for drugs in proteomics. Proteomics. 2003;3(4):380-91.

Arrich, J. Clinical application of mild therapeutic hypothermia after cardiac arrest. Crit Care Med. 2007;35(4):1041-7.

Arthur, P. G., G. P. Matich, W. W. Pang, D. Y. Yu and M. A. Bogoyevitch Necrotic death of neurons following an excitotoxic insult is prevented by a peptide inhibitor of $\mathrm{c}$-jun $\mathrm{N}$ terminal kinase. J Neurochem. 2007;102(1):65-76.

Asoh, S., I. Ohsawa, T. Mori, K. Katsura, T. Hiraide, Y. Katayama, M. Kimura, D. Ozaki, K. Yamagata and S. Ohta Protection against ischemic brain injury by protein therapeutics. Proc Natl Acad Sci U S A. 2002;99(26):17107-12.

Baell, J. B., P. J. Duggan and Y. P. Lok w-Conotoxins and approachs to their non-peptide mimetics. Aust. J. Chem. 2004;57(179-185.

Ballabh, P., A. Braun and M. Nedergaard The blood-brain barrier: an overview: structure, regulation, and clinical implications. Neurobiol Dis. 2004;16(1):1-13.

Barr, R. K., T. S. Kendrick and M. A. Bogoyevitch Identification of the critical features of a small peptide inhibitor of JNK activity. J Biol Chem. 2002;277(13):10987-97.

Bazzoni, G. and E. Dejana Endothelial cell-to-cell junctions: molecular organization and role in vascular homeostasis. Physiol Rev. 2004;84(3):869-901.

Beduneau, A., P. Saulnier and J. P. Benoit Active targeting of brain tumors using nanocarriers. Biomaterials. 2007;28(33):494767.

Benoit, J. P., N. Faisant, M. C. Venier-Julienne and P. Menei Development of microspheres for neurological disorders: from basics to clinical applications. J Control Release. 2000;65(12):285-96.

Bernard, S. A., T. W. Gray, M. D. Buist, B. M. Jones, W. Silvester, G. Gutteridge and K. Smith Treatment of comatose survivors of out-of-hospital cardiac arrest with induced hypothermia. N Engl J Med. 2002;346(8):557-63.

Bilsky, E. J., R. D. Egleton, S. A. Mitchell, M. M. Palian, P. Davis, J. D. Huber, H. Jones, H. I. Yamamura, J. Janders, T. P. Davis, F. Porreca, V. J. Hruby and R. Polt Enkephalin glycopeptide analogues produce analgesia with reduced dependence liability. J Med Chem. 2000;43(13):2586-90.

Borsello, T., P. G. Clarke, L. Hirt, A. Vercelli, M. Repici, D. F. Schorderet, J. Bogousslavsky and C. Bonny A peptide inhibitor of C-Jun $\mathrm{N}$-terminal kinase protects against excitotoxicity and cerebral ischemia. Nat Med. 2003;9(9):1180-6.

Bouwmeester, T., A. Bauch, H. Ruffner, P. O. Angrand, G. Bergamini, K. Croughton, C. Cruciat, D. Eberhard, J. Gagneur, S. Ghidelli, C. Hopf, B. Huhse, R. Mangano, A. M. Michon, M. Schirle, J. Schlegl, M. Schwab, M. A. Stein, A. Bauer, G. Casari, G. Drewes, A. C. Gavin, D. B. Jackson, G. Joberty, G. Neubauer, J. Rick, B. Kuster and G. Superti-Furga A physical and functional map of the human TNF-alpha/NF-kappa B signal transduction pathway. Nat Cell Biol. 2004;6(2):97-105.

Brasnjevic, I., H. W. M. Steinbusch, C. Schmitz and P. MartinezMartinez Delivery of peptide and protein drugs over the bloodbrain barrier. Progress in Neurobiology. 2009; In Press, Corrected Proof(

Brightman, M. W. and T. S. Reese Junctions between intimately apposed cell membranes in the vertebrate brain. J Cell Biol. 1969;40(3):648-77.

Bromont, C., C. Marie and J. Bralet Increased lipid peroxidation in vulnerable brain regions after transient forebrain ischemia in rats. Stroke. 1989;20(7):918-24.

Brott, T. and J. Bogousslavsky Treatment of acute ischemic stroke. N Engl J Med. 2000;343(10):710-22.

Brugidou, J., C. Legrand, J. Mery and A. Rabie The retro-inverso form of a homeobox-derived short peptide is rapidly internalised by cultured neurones: a new basis for an efficient intracellular delivery system. Biochem Biophys Res Commun. 1995;214(2):685-93.

Burda, J., M. E. Martin, A. Garcia, A. Alcazar, J. L. Fando and M. Salinas Phosphorylation of the alpha subunit of initiation factor 2 correlates with the inhibition of translation following transient cerebral ischaemia in the rat. Biochem J. 1994;302 ( Pt 2)(335-8.

Cao, G., W. Pei, H. Ge, Q. Liang, Y. Luo, F. R. Sharp, A. Lu, R. Ran, S. H. Graham and J. Chen In Vivo Delivery of a Bcl-xL Fusion Protein Containing the TAT Protein Transduction Domain Protects against Ischemic Brain Injury and Neuronal Apoptosis. J Neurosci. 2002;22(13):5423-31.

Castillo, J., E. Winer and P. Quesenberry Newer monoclonal antibodies for hematological malignancies. Exp Hematol. 2008;36(7):755-68.

Chan, P. H. Reactive oxygen radicals in signaling and damage in the ischemic brain. J Cereb Blood Flow Metab. 2001;21(1):214.

Chen, L. and S. D. Harrison Cell-penetrating peptides in drug development: enabling intracellular targets. Biochem Soc Trans. 2007;35(Pt 4):821-5.

Chikhale, E. G., K. Y. Ng, P. S. Burton and R. T. Borchardt Hydrogen bonding potential as a determinant of the in vitro 
and in situ blood-brain barrier permeability of peptides. Pharm Res. 1994;11(3):412-9.

Choi, S. H., D. W. Kim, S. Y. Kim, J. J. An, S. H. Lee, H. S. Choi, E. J. Sohn, S. I. Hwang, M. H. Won, T. C. Kang, H. J. Kwon, J. H. Kang, S. W. Cho, J. Park, W. S. Eum and S. Y. Choi Transduced human copper chaperone for Cu,Zn-SOD (PEP$1-\mathrm{CCS})$ protects against neuronal cell death. Mol Cells. 2005;20(3):401-8.

Colombo, A., M. Repici, M. Pesaresi, S. Santambrogio, G. Forloni and T. Borsello The TAT-JNK inhibitor peptide interferes with beta amyloid protein stability. Cell Death Differ. 2007;14(10):1845-8.

Cooper, D. A. and J. M. Lange Peptide inhibitors of virus-cell fusion: enfuvirtide as a case study in clinical discovery and development. Lancet Infect Dis. 2004;4(7):426-36.

Croxtall, J. D. and L. J. Scott Lanreotide Autogel: a review of its use in the management of acromegaly. Drugs. 2008;68(5):711-23.

DeGracia, D. J., R. W. Neumar, B. C. White and G. S. Krause Global brain ischemia and reperfusion: modifications in eukaryotic initiation factors associated with inhibition of translation initiation. J Neurochem. 1996;67(5):2005-12.

Degterev, A., Z. Huang, M. Boyce, Y. Li, P. Jagtap, N. Mizushima, G. D. Cuny, T. J. Mitchison, M. A. Moskowitz and J. Yuan Chemical inhibitor of nonapoptotic cell death with therapeutic potential for ischemic brain injury. Nat Chem Biol. 2005;1(2):112-9.

Derossi, D., A. H. Joliot, G. Chassaing and A. Prochiantz The third helix of the Antennapedia homeodomain translocates through biological membranes. J Biol Chem. 1994;269(14):10444-50.

Dhamija, R. K. and G. A. Donnan Time is brain--acute stroke management. Aust Fam Physician. 2007;36(11):892-5.

Dirnagl, U., C. ladecola and M. A. Moskowitz Pathobiology of ischaemic stroke: an integrated view. Trends Neurosci. 1999;22(9):391-7.

Drin, G., S. Cottin, E. Blanc, A. R. Rees and J. Temsamani Studies on the Internalization Mechanism of Cationic Cell-penetrating Peptides. J. Biol. Chem. 2003;278(33):31192-31201.

Egleton, R. D. and T. P. Davis Development of neuropeptide drugs that cross the blood-brain barrier. NeuroRx. 2005;2(1):44-53.

El-Andaloussi, S., T. Holm and U. Langel Cell-penetrating peptides: mechanisms and applications. Curr Pharm Des. 2005;11(28):3597-611.

Emerich, D. F., M. A. Tracy, K. L. Ward, M. Figueiredo, R. Qian, C. Henschel and R. T. Bartus Biocompatibility of poly (DLlactide-co-glycolide) microspheres implanted into the brain. Cell Transplant. 1999;8(1):47-58.

Esneault, E., V. Castagne, P. Moser, C. Bonny and M. Bernaudin $\mathrm{D}$-JNKi, a peptide inhibitor of c-Jun $\mathrm{N}$-terminal kinase promotes functional recovery after transient focal cerebral ischemia in rats. Neuroscience. 2008;152(2):308-20.

Fan, Y., L. Shi, Y. Gu, Y. Zhao, J. Xie, J. Qiao, G. Y. Yang, Y. Wang and C. Z. Lu Pretreatment with PTD-calbindin D 28k alleviates rat brain injury induced by ischemia and reperfusion. J Cereb Blood Flow Metab. 2007;27(4):719-28.

Fan, Y. F., C. Z. Lu, J. Xie, Y. X. Zhao and G. Y. Yang Apoptosis inhibition in ischemic brain by intraperitoneal PTD-BIR3-RING (XIAP). Neurochem Int. 2006;48(1):50-9.

Fischer, R., T. Waizenegger, K. Kohler and R. Brock A quantitative validation of fluorophore-labelled cell-permeable peptide conjugates: fluorophore and cargo dependence of import. Biochim Biophys Acta. 2002;1564(2):365-74.

Frankel, A. D. and C. O. Pabo Cellular uptake of the tat protein from human immunodeficiency virus. Cell. 1988;55(6):118993.

Gillardon, F., B. Bottiger, B. Schmitz, M. Zimmermann and K. A. Hossmann Activation of CPP-32 protease in hippocampal neurons following ischemia and epilepsy. Brain Res Mol Brain Res. 1997;50(1-2):16-22.

Goeddel, D. V., D. G. Kleid, F. Bolivar, H. L. Heyneker, D. G. Yansura, R. Crea, T. Hirose, A. Kraszewski, K. Itakura and A. D. Riggs Expression in Escherichia coli of chemically synthesized genes for human insulin. Proc Natl Acad Sci U S A. $1979 ; 76(1): 106-10$.

Goldberg, M. P. and D. W. Choi Combined oxygen and glucose deprivation in cortical cell culture: calcium-dependent and calcium-independent mechanisms of neuronal injury. J Neurosci. 1993;13(8):3510-24.

Gozes, I., M. Fridkinb, J. M. Hill and D. E. Brenneman Pharmaceutical VIP: prospects and problems. Curr Med Chem. 1999;6(11):1019-34.

Green, M. and P. M. Loewenstein Autonomous functional domains of chemically synthesized human immunodeficiency virus tat trans-activator protein. Cell. 1988;55(6):1179-88.

Grieb, P., R. E. Forster, D. Strome, C. W. Goodwin and P. C. Pape $\mathrm{O} 2$ exchange between blood and brain tissues studied with 1802 indicator-dilution technique. J Appl Physiol. 1985;58(6):1929-41.

Guan, J. Insulin-like growth factor-1 and its derivatives: potential pharmaceutical application for ischemic brain injury. Recent Patents CNS Drug Discov. 2008;3(2):112-27.

Guan, Q. H., D. S. Pei, Y. Y. Zong, T. L. Xu and G. Y. Zhang Neuroprotection against ischemic brain injury by a small peptide inhibitor of c-Jun N-terminal kinase (JNK) via nuclear and non-nuclear pathways. Neuroscience. 2006;139(2):60927.

Guegan, C., J. Braudeau, C. Couriaud, G. P. Dietz, P. Lacombe, M. Bahr, M. Nosten-Bertrand and B. Onteniente PTD-XIAP protects against cerebral ischemia by anti-apoptotic and transcriptional regulatory mechanisms. Neurobiol Dis. 2006;22(1):177-86.

Gulyaev, A. E., S. E. Gelperina, I. N. Skidan, A. S. Antropov, G. Y. Kivman and J. Kreuter Significant transport of doxorubicin into the brain with polysorbate 80-coated nanoparticles. Pharm Res. 1999;16(10):1564-9.

Haba, K., N. Ogawa, K. Mizukawa and A. Mori Time course of changes in lipid peroxidation, pre- and postsynaptic cholinergic indices, NMDA receptor binding and neuronal death in the gerbil hippocampus following transient ischemia. Brain Res. 1991;540(1-2):116-22.

Hacke, W., M. Kaste, E. Bluhmki, M. Brozman, A. Davalos, D. Guidetti, V. Larrue, K. R. Lees, Z. Medeghri, T. Machnig, D. Schneider, R. von Kummer, N. Wahlgren and D. Toni Thrombolysis with alteplase 3 to 4.5 hours after acute ischemic stroke. N Engl J Med. 2008;359(13):1317-29.

Heil, M. L., J. M. Decker, J. N. Sfakianos, G. M. Shaw, E. Hunter and C. A. Derdeyn Determinants of human immunodeficiency virus type 1 baseline susceptibility to the fusion inhibitors enfuvirtide and $\mathrm{T}-649$ reside outside the peptide interaction site. J Virol. 2004;78(14):7582-9.

Hellstrom, M., H. Gerhardt, M. Kalen, X. Li, U. Eriksson, H. Wolburg and C. Betsholtz Lack of pericytes leads to 
endothelial hyperplasia and abnormal vascular morphogenesis. J Cell Biol. 2001;153(3):543-53.

Hirt, L., J. Badaut, J. Thevenet, C. Granziera, L. Regli, F. Maurer, C. Bonny and J. Bogousslavsky D-JNKI1, a cell-penetrating c-Jun-N-terminal kinase inhibitor, protects against cell death in severe cerebral ischemia. Stroke. 2004;35(7):1738-43.

Hong, H. Y., J. S. Choi, Y. J. Kim, H. Y. Lee, W. Kwak, J. Yoo, J. T. Lee, T. H. Kwon, I. S. Kim, H. S. Han and B. H. Lee Detection of apoptosis in a rat model of focal cerebral ischemia using a homing peptide selected from in vivo phage display. J Control Release. 2008;

Hu, W., A. S. Philips, J. C. Kwok, M. Eisbacher and B. H. Chong Identification of nuclear import and export signals within Fli-1: roles of the nuclear import signals in Fli-1-dependent activation of megakaryocyte-specific promoters. Mol Cell Biol. 2005;25(8):3087-108

Janzer, R. C. and M. C. Raff Astrocytes induce blood-brain barrier properties in endothelial cells. Nature. 1987;325(6101):253-7.

Jo, D., A. Nashabi, C. Doxsee, Q. Lin, D. Unutmaz, J. Chen and H. E. Ruley Epigenetic regulation of gene structure and function with a cell-permeable Cre recombinase. Nat Biotechnol. 2001;19(10):929-33.

Joliot, A. and A. Prochiantz Transduction peptides: from technology to physiology. Nat Cell Biol. 2004;6(3):189-96.

Kacem, K., P. Lacombe, J. Seylaz and G. Bonvento Structural organization of the perivascular astrocyte endfeet and their relationship with the endothelial glucose transporter: a confocal microscopy study. Glia. 1998;23(1):1-10.

Kader, A., V. I. Frazzini, R. A. Solomon and R. R. Trifiletti Nitric oxide production during focal cerebral ischemia in rats. Stroke. 1993;24(11):1709-16.

Kaufmann, A. M. and E. R. Cardoso Aggravation of vasogenic cerebral edema by multiple-dose mannitol. J Neurosurg. 1992;77(4):584-9.

Kilic, E., G. P. Dietz, D. M. Hermann and M. Bahr Intravenous TAT-Bcl-XI is protective after middle cerebral artery occlusion in mice. Ann Neurol. 2002;52(5):617-22.

Kilic, U., E. Kilic, G. P. Dietz and M. Bahr Intravenous TAT-GDNF is protective after focal cerebral ischemia in mice. Stroke. 2003;34(5):1304-10.

Kim, D. W., W. S. Eum, S. H. Jang, S. Y. Kim, H. S. Choi, S. H. Choi, J. J. An, S. H. Lee, K. S. Lee, K. Han, T. C. Kang, M. H. Won, J. H. Kang, O. S. Kwon, S. W. Cho, T. Y. Kim, J. Park and S. Y. Choi Transduced Tat-SOD fusion protein protects against ischemic brain injury. Mol Cells. 2005;19(1):88-96.

Kleihues, P., K. A. Hossmann, A. E. Pegg, K. Kobayashi and V. Zimmermann Resuscitation of the monkey brain after one hour complete ischemia. III. Indications of metabolic recovery. Brain Res. 1975;95(1):61-73.

Kniesel, $\mathrm{U}$. and $\mathrm{H}$. Wolburg Tight junctions of the blood-brain barrier. Cell Mol Neurobiol. 2000;20(1):57-76.

Kreuter, J., R. N. Alyautdin, D. A. Kharkevich and A. A. Ivanov Passage of peptides through the blood-brain barrier with colloidal polymer particles (nanoparticles). Brain Res. 1995;674(1):171-4.

Kumar, P., H. Wu, J. L. McBride, K. E. Jung, M. H. Kim, B. L. Davidson, S. K. Lee, P. Shankar and N. Manjunath Transvascular delivery of small interfering RNA to the central nervous system. Nature. 2007;448(7149):39-43.

Lai, Y., L. Du, K. E. Dunsmore, L. W. Jenkins, H. R. Wong and R. $\mathrm{S}$. Clark Selectively increasing inducible heat shock protein
70 via TAT-protein transduction protects neurons from nitrosative stress and excitotoxicity. J Neurochem. 2005;94(2):360-6.

Laske, D. W., R. J. Youle and E. H. Oldfield Tumor regression with regional distribution of the targeted toxin TF-CRM107 in patients with malignant brain tumors. Nat Med. 1997;3(12):1362-8.

Lee, H. J., B. Engelhardt, J. Lesley, U. Bickel and W. M. Pardridge Targeting rat anti-mouse transferrin receptor monoclonal antibodies through blood-brain barrier in mouse. J Pharmacol Exp Ther. 2000;292(3):1048-52.

Lee, J. M., M. C. Grabb, G. J. Zipfel and D. W. Choi Brain tissue responses to ischemia. J Clin Invest. 2000;106(6):723-31.

Leker, R. R., A. Teichner, N. Grigoriadis, H. Ovadia, D. E. Brenneman, M. Fridkin, E. Giladi, J. Romano and I. Gozes NAP, a femtomolar-acting peptide, protects the brain against ischemic injury by reducing apoptotic death. Stroke. 2002;33(4):1085-92.

Levin, V. A. Relationship of octanol/water partition coefficient and molecular weight to rat brain capillary permeability. J Med Chem. 1980;23(6):682-4.

Lin, Y. Z., S. Y. Yao, R. A. Veach, T. R. Torgerson and J. Hawiger Inhibition of nuclear translocation of transcription factor NFkappa $B$ by a synthetic peptide containing a cell membranepermeable motif and nuclear localization sequence. J Biol Chem. 1995;270(24):14255-8.

Lipinski, C. A., F. Lombardo, B. W. Dominy and P. J. Feeney Experimental and computational approaches to estimate solubility and permeability in drug discovery and development settings. Adv Drug Deliv Rev. 2001;46(1-3):3-26

Lipton, P. Ischemic cell death in brain neurons. Physiol Rev. 1999;79(4):1431-568.

Liu, X. M., D. S. Pei, Q. H. Guan, Y. F. Sun, X. T. Wang, Q. X. Zhang and G. Y. Zhang Neuroprotection of Tat-GluR6-9c against neuronal death induced by kainate in rat hippocampus via nuclear and non-nuclear pathways. J Biol Chem. 2006;281(25):17432-45.

Maioriello, A. V., G. Chaljub, H. J. Nauta and M. Lacroix Chemical shift imaging of mannitol in acute cerebral ischemia. Case report. J Neurosurg. 2002;97(3):687-91.

Mangoni, M. E., A. Aumelas, P. Charnet, C. Roumestand, L. Chiche, E. Despaux, G. Grassy, B. Calas and A. Chavanieu Change in membrane permeability induced by protegrin 1 : implication of disulphide bridges for pore formation. FEBS Lett. 1996;383(1-2):93-8.

Martins, M. B. and I. Carvalho Diketopiperazines: biological activity and synthesis. Tetrahedron. 2007;63(40):9923-9932.

McCulloch, J., E. Ozyurt, C. K. Park, D. G. Nehls, G. M. Teasdale and D. I. Graham Glutamate receptor antagonists in experimental focal cerebral ischaemia. Acta Neurochir Suppl (Wien). 1993;57(73-9.

Michiue, H., K. Tomizawa, F. Y. Wei, M. Matsushita, Y. F. Lu, T. Ichikawa, T. Tamiya, I. Date and $\mathrm{H}$. Matsui The $\mathrm{NH} 2$ terminus of influenza virus hemagglutinin-2 subunit peptides enhances the antitumor potency of polyarginine-mediated p53 protein transduction. J Biol Chem. 2005;280(9):8285-9.

Moschos, S. A., S. W. Jones, M. M. Perry, A. E. Williams, J. S. Erjefalt, J. J. Turner, P. J. Barnes, B. S. Sproat, M. J. Gait and M. A. Lindsay Lung delivery studies using siRNA conjugated to TAT(48-60) and penetratin reveal peptide 
induced reduction in gene expression and induction of innate immunity. Bioconjug Chem. 2007;18(5):1450-9.

Mueller, J., I. Kretzschmar, R. Volkmer and P. Boisguerin Comparison of cellular uptake using 22 CPPs in 4 different cell lines. Bioconjug Chem. 2008;19(12):2363-74.

Nagel, F., B. H. Falkenburger, L. Tonges, S. Kowsky, C. Poppelmeyer, J. B. Schulz, M. Bahr and G. P. Dietz TatHsp70 protects dopaminergic neurons in midbrain cultures and in the substantia nigra in models of Parkinson's disease. J Neurochem. 2008;105(3):853-64.

Nakase, I., M. Niwa, T. Takeuchi, K. Sonomura, N. Kawabata, Y. Koike, M. Takehashi, S. Tanaka, K. Ueda, J. C. Simpson, A. T. Jones, Y. Sugiura and S. Futaki Cellular uptake of arginine-rich peptides: roles for macropinocytosis and actin rearrangement. Mol Ther. 2004;10(6):1011-22.

Namane, A., C. Gouyette, M. P. Fillion, G. Fillion and T. HuynhDinh Improved brain delivery of AZT using a glycosyl phosphotriester prodrug. J Med Chem. 1992;35(16):3039-44.

Nath, A., K. Psooy, C. Martin, B. Knudsen, D. S. Magnuson, N. Haughey and J. D. Geiger Identification of a human immunodeficiency virus type 1 Tat epitope that is neuroexcitatory and neurotoxic. J Virol. 1996;70(3):1475-80.

Negri, L., R. Lattanzi, F. Tabacco, B. Scolaro and R. Rocchi Glycodermorphins: opioid peptides with potent and prolonged analgesic activity and enhanced blood-brain barrier penetration. Br J Pharmacol. 1998;124(7):1516-22

Nicholls, D. and D. Attwell The release and uptake of excitatory amino acids. Trends Pharmacol Sci. 1990;11(11):462-8.

Novelli, A., J. A. Reilly, P. G. Lysko and R. C. Henneberry Glutamate becomes neurotoxic via the N-methyl-D-aspartate receptor when intracellular energy levels are reduced. Brain Res. 1988;451(1-2):205-12.

Oehlke, J., A. Scheller, B. Wiesner, E. Krause, M. Beyermann, E. Klauschenz, M. Melzig and M. Bienert Cellular uptake of an alpha-helical amphipathic model peptide with the potential to deliver polar compounds into the cell interior nonendocytically. Biochim Biophys Acta. 1998;1414(1-2):127-39.

Palian, M. M., V. I. Boguslavsky, D. F. O'Brien and R. Polt Glycopeptide-membrane interactions: glycosyl enkephalin analogues adopt turn conformations by NMR and CD in amphipathic media. J Am Chem Soc. 2003;125(19):5823-31.

Pardridge, W. M. Blood-brain barrier drug targeting enables neuroprotection in brain ischemia following delayed intravenous administration of neurotrophins. Adv Exp Med Biol. 2002;513(397-430.

Pardridge, W. M., Y. S. Kang, J. L. Buciak and J. Yang Human insulin receptor monoclonal antibody undergoes high affinity binding to human brain capillaries in vitro and rapid transcytosis through the blood-brain barrier in vivo in the primate. Pharm Res. 1995;12(6):807-16.

Pei, D. S., X. T. Wang, Y. Liu, Y. F. Sun, Q. H. Guan, W. Wang, J. Z. Yan, Y. Y. Zong, T. L. Xu and G. Y. Zhang Neuroprotection against ischaemic brain injury by a GluR6-9c peptide containing the TAT protein transduction sequence. Brain. 2006;129(Pt 2):465-79.

Peitz, M., K. Pfannkuche, K. Rajewsky and F. Edenhofer Ability of the hydrophobic FGF and basic TAT peptides to promote cellular uptake of recombinant Cre recombinase: a tool for efficient genetic engineering of mammalian genomes. Proc Natl Acad Sci U S A. 2002;99(7):4489-94.
Peterson, K., S. Carson and N. Carney Hypothermia treatment for traumatic brain injury: a systematic review and meta-analysis. J Neurotrauma. 2008;25(1):62-71.

Pharmaceutical Research and Manufacturers of America (2006). Medicines in development for neurological disorders. Washington, DC, Pharmaceutical Research and Manufacturers of America: 1-24.

Polderman, K. H., S. M. Peerdeman and A. R. Girbes Hypophosphatemia and hypomagnesemia induced by cooling in patients with severe head injury. J Neurosurg. 2001;94(5):697-705.

Polt, R., F. Porreca, L. Z. Szabo, E. J. Bilsky, P. Davis, T. J. Abbruscato, T. P. Davis, R. Harvath, H. I. Yamamura and V. J. Hruby Glycopeptide enkephalin analogues produce analgesia in mice: evidence for penetration of the blood-brain barrier. Proc Natl Acad Sci U S A. 1994;91(15):7114-8.

Rapoport, S. I., W. R. Fredericks, K. Ohno and K. D. Pettigrew Quantitative aspects of reversible osmotic opening of the blood-brain barrier. Am J Physiol. 1980;238(5):R421-31.

Reese, T. S. and M. J. Karnovsky Fine structural localization of a blood-brain barrier to exogenous peroxidase. J Cell Biol. 1967;34(1):207-17.

Rehncrona, S., L. Mela and B. K. Siesjo Recovery of brain mitochondrial function in the rat after complete and incomplete cerebral ischemia. Stroke. 1979;10(4):437-46.

Reissmann, T., A. V. Schally, P. Bouchard, H. Riethmiiller and J. Engel The LHRH antagonist cetrorelix: a review. Hum Reprod Update. 2000;6(4):322-31.

Richard, J. P., K. Melikov, E. Vives, C. Ramos, B. Verbeure, M. J. Gait, L. V. Chernomordik and B. Lebleu Cell-penetrating peptides. A reevaluation of the mechanism of cellular uptake. J Biol Chem. 2003;278(1):585-90.

Rojas, M., J. P. Donahue, Z. Tan and Y. Z. Lin Genetic engineering of proteins with cell membrane permeability. Nat Biotechnol. 1998;16(4):370-5.

Rosenberg, G. A., M. Navratil, F. Barone and G. Feuerstein Proteolytic cascade enzymes increase in focal cerebral ischemia in rat. J Cereb Blood Flow Metab. 1996;16(3):360-6.

Rothbard, J. B., S. Garlington, Q. Lin, T. Kirschberg, E. Kreider, P. L. McGrane, P. A. Wender and P. A. Khavari Conjugation of arginine oligomers to cyclosporin A facilitates topical delivery and inhibition of inflammation. Nat Med. 2000;6(11):1253-7.

Rousselle, C., P. Clair, J. M. Lefauconnier, M. Kaczorek, J. M. Scherrmann and J. Temsamani New advances in the transport of doxorubicin through the blood-brain barrier by a peptide vector-mediated strategy. Mol Pharmacol. 2000;57(4):679-86.

Russell, M. W., M. A. Soliman, D. Schriemer and K. Riabowol ING1 protein targeting to the nucleus by karyopherins is necessary for activation of p21. Biochem Biophys Res Commun. 2008;374(3):490-5

Safar, P., M. Klain and S. Tisherman Selective brain cooling after cardiac arrest. Crit Care Med. 1996;24(6):911-4.

Schon, M. P. Efalizumab in the treatment of psoriasis: mode of action, clinical indications, efficacy, and safety. Clin Dermatol. 2008;26(5):509-514

Schulze, C. and J. A. Firth Immunohistochemical localization of adherens junction components in blood-brain barrier microvessels of the rat. J Cell Sci. 1993;104 ( Pt 3)(773-82. 
Schwarze, S. R., A. Ho, A. Vocero-Akbani and S. F. Dowdy In vivo protein transduction: delivery of a biologically active protein into the mouse. Science. 1999;285(5433):1569-72.

Siegal, T., R. Rubinstein, F. Bokstein, A. Schwartz, A. Lossos, E. Shalom, R. Chisin and J. M. Gomori In vivo assessment of the window of barrier opening after osmotic blood-brain barrier disruption in humans. J Neurosurg. 2000;92(4):599605.

Sik Eum, W., D. Won Kim, I. Koo Hwang, K.-Y. Yoo, T.-C. Kang, S. Ho Jang, H. Soon Choi, S. Hyun Choi, Y. Hoon Kim, S. Young Kim, H. Yil Kwon, J. Hoon Kang, O.-S. Kwon, S.-W. Cho, K. Soo Lee, J. Park, M. Ho Won and S. Young Choi In vivo protein transduction: biologically active intact pep-1superoxide dismutase fusion protein efficiently protects against ischemic insult. Free Radical Biology and Medicine. 2004;37(10):1656-1669.

Stewart, K. M., K. L. Horton and S. O. Kelley Cell-penetrating peptides as delivery vehicles for biology and medicine. Org Biomol Chem. 2008;6(13):2242-55.

Suzuki, T., S. Futaki, M. Niwa, S. Tanaka, K. Ueda and Y. Sugiura Possible existence of common internalization mechanisms among arginine-rich peptides. J Biol Chem. 2002;277(4):2437-43.

The Hypothermia After Cardiac Arrest Study Group Mild therapeutic hypothermia to improve the neurologic outcome after cardiac arrest. N Engl J Med. 2002;346(8):549-56.

Tiwari, S. B. and M. M. Amiji A review of nanocarrier-based CNS delivery systems. Curr Drug Deliv. 2006;3(2):219-32.

Tsubery, H., M. Mironchik, M. Fridkin and Y. Shechter Prolonging the action of protein and peptide drugs by a novel approach of reversible polyethylene glycol modification. J Biol Chem. 2004;279(37):38118-24.

Wadia, J. S., R. V. Stan and S. F. Dowdy Transducible TAT-HA fusogenic peptide enhances escape of TAT-fusion proteins after lipid raft macropinocytosis. Nat Med. 2004;10(3):310-5.
Wang, Q., X. Gou, L. Xiong, W. Jin, S. Chen, L. Hou and L. Xu Trans-activator of transcription-mediated delivery of NEP1-40 protein into brain has a neuroprotective effect against focal cerebral ischemic injury via inhibition of neuronal apoptosis. Anesthesiology. 2008;108(6):1071-80.

Watt, P. M. Screening for peptide drugs from the natural repertoire of biodiverse protein folds. Nat Biotechnol. 2006;24(2):177-83.

Wei, X., Z. Miou and M. Baudry Neuroprotection by cell permeable TAT-mGluR1 peptide in ischemia: synergy between carrier and cargo sequences. Neuroscientist. 2008;14(5):409-14.

Wender, P. A., D. J. Mitchell, K. Pattabiraman, E. T. Pelkey, L. Steinman and J. B. Rothbard The design, synthesis, and evaluation of molecules that enable or enhance cellular uptake: peptoid molecular transporters. Proc Natl Acad Sci U S A. 2000;97(24):13003-8.

Wiegler, K., C. Bonny, D. Coquoz and L. Hirt The JNK inhibitor XG-102 protects from ischemic damage with delayed intravenous administration also in the presence of recombinant tissue plasminogen activator. Cerebrovasc Dis. 2008;26(4):360-6.

Witt, K. A., T. J. Gillespie, J. D. Huber, R. D. Egleton and T. P. Davis Peptide drug modifications to enhance bioavailability and blood-brain barrier permeability. Peptides. 2001;22(12):2329-43

Yoshikawa, T., T. Sugita, Y. Mukai, N. Yamanada, K. Nagano, H. Nabeshi, Y. Yoshioka, S. Nakagawa, Y. Abe, H. Kamada, S. Tsunoda and $\mathrm{Y}$. Tsutsumi Organelle-targeted delivery of biological macromolecules using the protein transduction domain: potential applications for Peptide aptamer delivery into the nucleus. J Mol Biol. 2008;380(5):777-82.

Zhang, Y. and W. M. Pardridge Mediated efflux of IgG molecules from brain to blood across the blood-brain barrier. J Neuroimmunol. 2001;114(1-2):168-72.

Zlokovic, B. V. The blood-brain barrier in health and chronic neurodegenerative disorders. Neuron. 2008;57(2):178-201. 